\title{
FRAGMENTOS DE ORIENTALISMO ESPAÑOL DEL S. XVII ${ }^{1}$
}

\author{
FERNANDO RODRÍGUEZ MEDIANO \\ CSIC, Madrid
}

RESUMEN: Este artículo trata de ser una contribución al estudio de una época especialmente mal conocida de la historia de los estudios árabes en España, el s. XVII. Frente a la interpretación tradicional, que considera ese siglo como un eclipse del arabismo español los ejemplos reunidos aquí muestran una continuidad de la erudición oriental en España durante todo ese siglo, relacionada en buena medida con las grandes polémicas que suscitó la falsificación de los Libros Plúmbeos del Sacromonte. Esa continuidad se demuestra, en parte, por la existencia de una importante actividad de traducción de textos árabes, muchos de los cuales son aún mal conocidos o están, simplemente, perdidos. Entre los personajes tratados en este artículo se encuentran algunos nombres muy importantes en la historiografía española del s. XVII, como el Marqués de Mondéjar, lo que muestra el papel central que se adjudicaba a la lengua árabe para la construcción de la historia de España.

Palabras Clave: Arabismo. Orientalismo. Traducción. Siglo XVII. España. Historia Cultural. Historiografía.

ABSTRACT: This paper looks at Arabic Studies in 17th-century Spain. According to the traditional interpretation, this century saw an «eclipse» in Spanish oriental scholarship. On the contrary, I will try to show that there was a continuous and permanent interest in Arabic Studies in Spain, not least because of the numerous questions raised by the forgery of the Lead Books of Sacromonte of the late 16th century. To demonstrate this continuity, I study several translations of Arabic texts into Spanish, some hitherto unknown or considered lost. I also discuss the cases of various prominent Spanish scholars and historians of the time, who, like the

${ }^{1}$ Este artículo es resultado del trabajo de investigación que llevamos a cabo dentro del proyecto de investigación «Los Libros Plúmbeos del Sacromonte: edición y estudio del texto árabe» (HUM2004-02018/FILO), cuya Investigadora Principal es Mercedes García-Arenal. Con ella discuto y comparto ideas y bibliografía constantemente, así que buena parte de lo mejor de este texto se debe a ella. También lo ha leído y dicutido, en una primera redacción, Cristina Jular. 
marquis of Mondéjar, devoted themselves to Arabic Studies as an essential instrument for constructing the history of Spain. This paper looks at Arabic Studies in 17th-century Spain. According to the traditional interpretation, this century saw an «eclipse» in Spanish oriental scholarship. On the contrary, I will try to show that there was a continuous and permanent interest in Arabic Studies in Spain, not least because of the numerous questions raised by the forgery of the Lead Books of Sacromonte of the late 16th century. To demonstrate this continuity, I study several translations of Arabic texts into Spanish, some hitherto unknown or considered lost. I also discuss the cases of various prominent Spanish scholars and bistorians of the time, who, like the marquis of Mondéjar, devoted themselves to Arabic Studies as an essential instrument for constructing the history of Spain.

KEY WORDS: Arabic Studies. Orientalism. Translation. Spain. Cultural History. Historiography. Seventeenth Century.

En su clásico estudio sobre la historia del arabismo español, James T. Monroe afirmaba que, durante el s. XVII, los estudios árabes en España sufrieron un «eclipse», una especie de vacío en el que sólo era posible señalar algunas excepciones: una perdida historia de al-Andalus, obra de un Marco Obelio Citeroni, titulada Suma que trata del tiempo cuando los mahometanos ganaron a África, y cómo después pasaron a España... vuelta de arábigo en romance, y que incluía traducciones de algunos poemas árabes; o el Tesoro de la lengua castellana de Sebastián de Covarrubias, quien, para trazar la etimología de algunas palabras de origen árabe, había tenido que consultar al intérprete real Diego de Urrea, o a los escritos de Francisco de Guadix ${ }^{2}$. En general, la narración más o menos aceptada sobre la historia de los estudios árabes en España asume esta visión, y señala el s. XVIII como un momento de resurgir de los mismos, gracias, entre otras cosas, a la importante actividad de Miguel Casiri, monje maronita que realizó un catálogo ya clásico de los manuscritos árabes de El Escorial ${ }^{3}$, y cuya labor es sin duda una de las raíces del arabismo español propiamente moderno. Esta especie de agujero negro que el s. XVII representa para los estudios árabes en España se acentuaría, además, por la comparación con lo que ocurría en otras partes de Europa, donde el desarrollo de la erudición oriental había sido extraordinario durante los s. XVI y XVII, gracias a la actividad de grandes estudiosos como Thomas van Erpen o Tomás Erpenius en los Países Bajos, o de Giovanni Battista Raimondi en Italia ${ }^{4}$, por citar sólo un par de ejemplos desta-

2 Monroe, James T., Islam and the Arabs in Spanish Scholarship (Sixteenth Century to the Present), Leiden, 1970, 23.

3 Casiri, M., Bibliotheca Arabico-Hispana Escurialensis, reproducción de la ed. de 1760-70, Osnabrück, 1969.

${ }^{4}$ La bibliografía general sobre el orientalismo europeo en los ss. XVI y XVII es amplia. Por resaltar algunos estudios generales y ya clásicos, citaré SEGESVARY, Victor, L'Islam et la Réforme. Étude sur l'attitude des réformateurs zurichois envers l'Islam (1510-1550), Lausanne, Éditions l'Age 
cados; actividad erudita que implicaba una actividad igualmente notable en el campo de la impresión de textos en lenguas orientales y, más concretamente, en árabe.

Frente a esta visión sólidamente establecida, el objetivo de este artículo será mostrar la persistencia del interés por los estudios árabes en España durante el s. XVII, y las implicaciones de carácter más general que tales estudios poseían. Aunque el hilo narrativo de mi texto será por fuerza fragmentario, basado sobre todo en la acumulación de ejemplos concretos, propongo comprender tales ejemplos dentro de una perspectiva general más amplia y coherente, que abarca un proceso desarrollado durante los ss. XVI y XVII. En general, conocemos bien las razones que provocaron la intensificación del estudio de las lenguas orientales en Europa en época moderna: el interés por la hermenéutica de los textos sagrados condujo a una creciente dedicación al estudio del hebreo 5 (considerado a menudo como la lengua original de la humanidad), y, en menor medida, de otras lenguas orientales cercanas como el siriaco o el árabe. El contacto sistemático con las iglesias cristianas orientales ${ }^{6}$, y los intentos de unificación con las mismas, provocó un intercambio diplomático e intelectual que culminó con un hecho tan significativo e importante como la fundación del Colegio Maronita de Roma en 1584. Tal contacto con el cristianismo oriental facilitó la presencia en toda Europa de eruditos e intectuales maronitas, y, en general, la impresión y divulgación de varios textos sagrados del cristianismo en su versión árabe. La conciencia, además, de que existía un gran cuerpo de conocimiento contenido en los libros árabes, persas o turcos, condujo a los primeros intentos sistemáticos de recopilación y formación de fondos de manuscritos orientales en las bibliotecas europeas, como la Vaticana ${ }^{7}$; manuscritos que eran a menudo obtenidos por embajadores y viajeros tan señalados como Pietro della Valle o los hermanos Vecchietti.

Dentro de ese panorama general, el caso español presenta varias singularidades muy importantes: la lengua árabe y el Islam no eran para los españoles

d'Homme, 1978; BARTHOld, V.-V., La découverte de l'Asie. Histoire de l'Orientalisme en Europe et en Russie, trad. francesa de B. Nikitine, Payot, Paris, 1947; Rodinson, Maxime, La fascination de l'Islam, Paris, Maspero, 1980.

${ }^{5}$ Las peculiares e importantes derivaciones de este interés por el hebreo hacia lo que se ha llamado la cábala cristiana son bien conocidas. Quizás ninguna figura represente tan bien esta fusión de intereses hermenéuticos, místicos y orientalistas como Guillaume Postel; v., por ejemplo, Kuntz, M.L., Guillaume Postel, Prophet of the Restitution of All Things: His Life and Thought, La HayaBoston, 1981, donde se podrán encontrar numerosísimas y fundamentales referencias bibliográficas sobre la figura de Postel, debidas a autores como W. Bouwsma o F. Secret.

${ }^{6}$ Para algunos detalles de esos primeros contactos con las iglesias orientales, v., por ejemplo, SolA, José C., «El P. Juan Bautista Eliano. Un documento autobiográfico inédito», Archivum Historicum Societatis Iesu, (Roma) 14 (1935), 291-331, donde se destaca el papel del jesuita converso Juan Bautista Eliano y de sus viajes orientales a partir de 1561.

7 V. el hermoso libro de LEVI Della VIDA, G., Ricerche sulla formazione del più antico fondo dei manoscritti orientali della Biblioteca Vaticana, Ciudad del Vaticano, 1939. 
objeto de un interés más o menos lejano o erudito, sino una presencia cierta en la historia más inmediata de la Península Ibérica, en el paisaje de muchas ciudades y, sobre todo, en la existencia de los moriscos, una importantísima población de origen árabe y musulmán. La cuestión de los moriscos traspasaba, durante el s. XVI, muchas cuestiones cruciales para España: desde la relación con el Imperio Otomano o con Marruecos, hasta los problemas acuciantes de asimilación y evangelización, que fueron derivando hacia medidas cada vez más restrictivas en cuanto al uso de la lengua árabe, de los trajes o de las costumbres moriscas. Todo ello provocó, como se sabe, la sangrienta Guerra de las Alpujarras, y, finalmente, la expulsión definitiva.

Todas estas cuestiones se reflejan de manera esencial en un acontecimiento que es, en mi opinión, central para el tema de este artículo: la falsificación del pergamino de la Torre Turpiana y de los libros Plúmbeos del Sacromonte ${ }^{8}$. Como se sabe, en 1588, al derribar el alminar de la antigua mezquita de Granada, apareció una caja que contenía, entre otras cosas, un extraño pergamino con textos en árabe, latín y castellano, incluyendo un texto de carácter profético y la firma de S. Cecilio, legendario obispo de Granada y discípulo de Santiago Apóstol ${ }^{9}$. Unos años más tarde, a partir de 1595, en el monte Valparaíso, cercano a Granada, comenzaron a aparecer una serie de láminas de plomo, grabadas en unos caracteres extraños, llamados salomónicos, que eran en realidad caracteres árabes un poco deformados. Estas láminas de plomo contenían el texto de varios libros que, atribuidos a la Virgen María, a Santiago apóstol o a sus supuestos discípulos Cecilio, Hiscio y Tesiphón, reproducían mensajes diversos de corte doctrinal o profético. La aparición de estos textos dio lugar, como se sabe, a una extraordinaria, encendida y prolongada polémica erudita y teológica, que implicó a algunos de los hombres más sabios de su tiempo, como Benito Arias Montano, Pedro de Valencia o Ignacio de Las Casas. Frente a quienes sostenían la falsedad del pergamino y de los Plomos, el Arzobispo d. Pedro de Castro defendió la autenticidad de los mismos, pues constituían la prueba de la antigüedad de la iglesia de Granada y su vinculación directa con los orígenes del cristianismo, por encima de su inmediato pasado musulmán. De esta manera, aquellos difíciles textos árabes implicaban perentoriamente la cuestión de los orígenes de España y de los españoles, tan importante para la

\footnotetext{
${ }^{8}$ Aunque se trata de un tema conocido y tratado desde antiguo, estudios recientes han proporcionado nuevas y más amplias perspectivas de comprensión de un asunto que tuvo, en su día, una espectacular y polémica recepción. Para un acercamiento a esas nuevas perspectivas, y a sus autores, hay que consultar los dos volúmenes monográficos de la revista $\mathrm{Al}$-Qanțara (Madrid) editados por García-AReNAL, M., 23 (2002) 342-543; y 24 (2003) 295-573. El contenido de ambos números será publicado próximamente en un volumen independiente por las Universidades de Granada y Valencia.

9 Para la edición del pergamino, que se encuentra hoy depositado en la Abadía del Sacromonte, v. VAN KoningsvelD, P.S. y Wiegers, G.A., "The Parchment of the "Torre Turpiana"; The Original Document and Its Early Interpreters», Al-Qanțara (Madrid) 24 (2003), 327-358.
} 
historiografía de la época. Más aún: si parte del texto del pergamino de la Torre Turpiana estaba escrito en árabe y en castellano del s. XVI, ¿cabía suponer que tales lenguas se hablaban en la península Ibérica en una fecha tan temprana como el s. I de la era cristiana? ¿Era el castellano una de las lenguas de Babel? ¿Podía el árabe ser separado de su carácter islámico? Todos estos problemas preocuparon de manera urgente, y no sólo desde el punto de vista erudito, a personajes de la talla de Bernardo de Aldrete. Además, el texto de los Plomos entraba directamente en cuestiones tan importantes en ese momento como la posible visita a España del apóstol Santiago, o el dogma de la inmaculada concepción de la Virgen María, en cuyo favor argumentaban.

Desde los primeros momentos, los críticos de la autenticidad de estos textos se dieron cuenta de que contenían proposiciones difícilmente aceptables por la ortodoxia católica, y directamente identificables con el islam. Sin embargo, las propias circunstancias de la transmisión textual y la traducción de los libros están llenas de confusión, pues sabemos que el arzobispo d. Pedro de Castro supervisaba directamente las traducciones de los libros, y que rechazaba las que consideraba que no se ajustaban a su propio concepto de lo que debía ser su contenido. Los libros y el pergamino fueron llevados finalmente al Vaticano, que en 1681 dictaminó su falsedad, aunque no la de las reliquias que aparecieron junto con ellos. Dado que todos, libros y reliquias, permanecieron ocultos en el Archivo Vaticano hasta el año 2000, en que fueron devueltos a la iglesia de Granada, en el día de hoy carecemos incluso de una edición de los textos originales, por lo que tenemos que conformarnos con las transcripciones y traducciones de la época, que deben ser sometidas, como queda dicho, a una rigurosa crítica textual. Carecemos, también, de estudio definitivo sobre la sucesión y secuencia de los descubrimientos ${ }^{10}$, que esclarezca las auténticas intenciones de los falsificadores, aunque podemos sospechar la identidad de los mismos, o al menos, de los más significados. Desde muy pronto se señaló a los moriscos Alonso del Castillo y Miguel de Luna como los autores directos de los textos. Los dos eran médicos, intérpretes de árabe, y fueron los primeros expertos que fueron convocados a trabajar en la traducción del pergamino y los libros. Ambas figuras son interesantísimas. El primero trabajó como intérprete regio en asuntos como la guerra de las Alpujarras, la traducción de las inscripciones árabes de la Alhambra o la catalogación de los manuscritos árabes de El Escorial ${ }^{11}$; el segundo es conocido, entre otras cosas, por ser el autor de una apasionante Historia verdadera del Rey Don Rodrigo ${ }^{12}$, repleta de falsificaciones desde el punto de vista histórico, pero plena de sentido dentro del medio intelectual en

${ }^{10}$ Quizás, la excepción más destacada a esta afirmación sea el clásico libro de AlONso, C., Los apócrifos del Sacromonte (estudio histórico), Valladolid, 1979.

${ }_{11}$ Cabanelas, D., El morisco granadino Alonso del Castillo, Granada, 1965.

12 Márquez Villanueva, F., «La voluntad de leyenda de Miguel de Luna» en El problema morisco (desde otras laderas), Madrid, 1992, 45-97; y el estudio preliminar de BERNABÉ PONS, L., a la edición facsímil de la Historia verdadera del Rey Don Rodrigo, Granada, 2001. 
el que los Plomos fueron posibles. M. García-Arenal ${ }^{13}$ ha señalado uno de los lugares centrales de ese medio, donde pudo haber nacido la inspiración de la falsificación: las tertulias literarias de grandes familias moriscas granadinas, como los Granada-Venegas. Estos moriscos, descendientes de familias nobles de época nazarí, jamás fueron expulsados de España, y argumentaron que la nobleza de sus antepasados era desligable del pasado musulmán del Reino de Granada; una estrategia, pues, de deslindar lo árabe de lo musulmán, que en su caso fue bastante exitosa, pues lograron evitar la expulsión. Hay que señalar, sin embargo, que en esta estrategia coincidieron con los intereses de importantes sectores de la iglesia granadina, que se convirtieron en los principales defensores de la autenticidad de los Plomos, donde se veía una prueba del antiquísimo vínculo de Granada con el origen del cristianismo. De hecho, la falsificación dejó una huella durable en la geografía sagrada de la ciudad, comenzando por el cambio de nombre del monte Valparaíso, que pasó a llamarse Sacromonte, y en cuya cima d. Pedro de Castro fundó la abadía que lleva ese nombre.

Este pequeño resumen no pretende agotar todas las implicaciones que posee el asunto de los Plomos del Sacromonte, sino señalar algunas de las vías que marcaron el interés por el estudio de los temas árabes en la España moderna y que se hicieron evidentes en un asunto de tan extraordinaria repercusión. Para mi propósito en este artículo, comenzaré precisamente por seguir la huella de alguno de los personajes que estuvieron presentes en la traducción de los libros, y cuya cualificación inicial era precisamente la de ser considerados expertos en lengua árabe.

Con la aparición del pergamino de la Torre Turpiana y de los Libros Plúmbeos del Sacromonte, se hizo necesario el concurso de traductores y expertos en lengua árabe. Entre los primeros nombres que nos encontramos figuran precisamente los de Alonso del Castillo y Miguel de Luna, que comenzaron a trabajar desde el hallazgo mismo del pergamino bajo la supervisión del licenciado Francisco López Tamarid, intérprete de la Inquisición de Granada y racionero de su catedral. Años más tarde, los mismos Castillo y Luna aparecen trabajando en la traducción de los libros plúmbeos junto con una tercera persona, hasta ahora menos conocida: Diego de Urrea Conca. Mercedes García-Arenal y yo mismo hemos desvelado distintos aspectos de la fascinante personalidad de este personaje ${ }^{14}$ : de origen calabrés, fue hecho cautivo de niño por corsarios musul-

13 «El entorno de los Plomos: historiografía y linaje», Al-Qanțara (Madrid) 24 (2003), 295326. Un libro reciente sobre el tema de las academias literarias en Granada es esta época es OsuNA, I., Poesía y academia en Granada en torno a 1600: la Poética Silva, Sevilla, 2003.

${ }_{14}$ Rodríguez Mediano, F. y García-Arenal, M., «Diego de Urrea y algún traductor más: en torno a las versiones de los 'Plomos'», Al-Qantara (Madrid) 23 (2002) 499-516; y RoDríGuEZ Mediano, F., «Diego de Urrea en Italia», Al-Qantara (Madrid) 25 (2004) 183-202. Ambos textos están fundidos, corregidos y bastante ampliados, en Rodríguez MEDiano, F. y GarCía-ARENAL, M., «De Diego de Urrea a Marcos Dobelio, intérpretes y traductores de los Plomos», en GARCíAArenal, M. (ed.), Los Plomos del Sacromonte: invención y tesoro, Granada-Valencia (en prensa) 
manes, llevado al norte de África y educado en la madrasa de Tremecén. Llegó a ser un gran ulema, y a trabajar como secretario para diversos señores otomanos con el nombre de Morato Aga. Ya mayor, regresó a Sicilia, no sabemos si a la fuerza o por propia voluntad, y se reconcilió ante la Inquisición en octubre de 1589, adoptando el nombre de Diego de Urrea, para entrar a trabajar al servicio del conde de Alba de Liste, virrey de Sicilia. En una fecha indeterminada alrededor de 1591, Urrea vino a España, y, trabajando al servicio de la monarquía, realizó distintas actividades relacionadas con su amplio conocimiento de lenguas orientales, especialmente el árabe, pero también el turco o el persa. Así estuvo, como hemos visto, relacionado con la traducción de los Plomos del Sacromonte, aunque su trabajo no llegó a agradar al arzobispo d. Pedro de Castro. Realizó también, a partir de 1598, un catálogo bilingüe de los manuscritos árabes de El Escorial ${ }^{15}$, y se ocupó de diferentes encargos reales, entre los que destaca, sin duda, la misión de intérprete-intermediario que realizó ante el sultán marroquí Muley Muhammad al-Sayj al-Ma'mūn, conocido en las fuentes hispanas como Muley Xeque, cuando éste viajó a España en 1610 para negociar la entrega de Larache a los españoles a cambio de la ayuda militar de éstos en la guerra civil que entonces se estaba desarrollando en Marruecos; curiosamente, Muley Xeque y Diego de Urrea habían sido condiscípulos cuando ambos estudiaban en la madrasa de Tremecén ${ }^{16}$.

Otros aspectos de la personalidad de Urrea como arabista resultan también interesantes. Sabemos, por ejemplo, que fue profesor privado de árabe de los hermanos Leonardo de Argensola. Sabemos también que fue autor de una historia de España desde la conquista musulmana, sacada «de las Chronicas que guarda el Turco y el rey de Marruecos» ${ }^{17}$, y que en cierto modo aspiraba a desafiar las falsedades de la Historia verdadera de Miguel de Luna: recuérdese que éste pretendía ser sólo el traductor de una vieja crónica árabe, en un recurso narrativo que poco después parodiaría el propio Cervantes en el Quijote. Como contaba Bartolomé Leonardo de Argensola en una carta de 1595, «[...] el libro [...] de la perdición de España [...] estoy cierto de que sentirá dél lo siguiente que aunque su autor dize que es historia verdadera traduzida de arábigo, se echa de ver su famosa mentira é invención despropositada, á lo menos en consideración de historia, y hase echado á perder poniendo por las márgenes los vocablos arábigos que traduze, porque él vino á esta corte donde luego se topó con Urrea, el qual lo cogió en ochocientas mentiras con que lo confundió» ${ }^{18}$.

15 Publicado por Morata, N., «Un catálogo de los fondos árabes primitivos de El Escorial», Al-Andalus (Madrid) 2 (1934) 87-181.

16 Para este asunto, v. García-Arenal, Mercedes, Rodríguez Mediano, Fernando y El Hour, Rachid, Cartas marruecas. Documentos de Marruecos en archivos españoles (siglos XVI-XVII), Madrid, CSIC, 2002.

${ }_{17}$ Carta de Bartolomé Leonardo de Argensola, 8 de abril de 1596, citada en CONDE DE LA VIÑAZA, Los cronistas de Aragón, ed. facsímil del original de 1904, Zaragoza, 1986, 95.

18 Ibid. 
Aunque la traducción de Urrea no se conserva, o no ha sido identificada hasta ahora, todo el episodio puede valer como ejemplo de los usos historiográficos que, en este momento de finales del s. XVI y comienzos del XVII, se daban al árabe y a los textos árabes, $\mathrm{y}$, en general, a la necesidad de utilizar las fuentes árabes para confeccionar la historia de España. Otra de las facetas interesantes del arabismo de Urrea es su nombramiento como catedrático de árabe en la Universidad de Alcalá de Henares, cuestión en la que me detendré un momento.

La enseñanza del árabe en las universidades españolas durante el s. XVI se enfrentó a numerosas dificultades. Algún intento más o menos conocido, como el de la Universidad de Salamanca, tan ligado a la experiencia vital del famoso humanista Nicolas Clénard durante su estancia en España ${ }^{19}$ se resolvió en un fracaso $^{20}$. Como explicaba Bataillon, «l'Espagne de la Renaissance était à la fois le pays le mieux désigné pour devenir une pépinière d'arabisants et le pays le moins disposé à jouer ce rôle» ${ }^{21}$. Sin embargo, el s. XVI se cierra con la adjudicación de una cátedra de árabe a Diego de Urrea en la Universidad de Alcalá, a instancias de Felipe II. Adscrita al Colegio Trilingüe, y dotada de la asignación debida a cada colegial, la cátedra fue proveída el 8 de agosto de 1593 . La actividad de Diego de Urrea como profesor en Alcalá debió ser intermitente, requerido por su trabajo al servicio del rey en El Escorial, que le obligaba a interrumpir sus clases durante algunas temporadas. A pesar de esos inconvenientes, el Claustro decidió, en 1595, la renovación de su cátedra a petición del propio Urrea, que aducía que «a la Universidad le constava ques muy suficiente para enseñar la lengua aráviga, pues que en el dicho tiempo a sacado discípulo que podía enseñar la dicha lengua aráviga [...] y ottros muchos religiosos y legos y por orden de el Rey nuestro señor se an traýdo muchos libros arávigos y a servido ... [?] a Su Magestad ansí de intrepretaciones de libros»; beneficios reconocidos por el claustro de la Universidad. La última referencia que he encontrado a esta cátedra de Urrea es de 1597 , y se refiere a la queja de los alumnos de que Urrea sólo impartía los «principios arávigos», y que no quería más pasar adelante en la enseñanza de la lengua cuando se lo pedían ${ }^{22}$.

En general, todo estas noticias muestran que Urrea estaba muy ocupado en el servicio del rey (catalogando los manuscritos de El Escorial, traduciendo los libros plúmbeos del Sacromonte, informando sobre libros árabes que llegaban a la corte y, más tarde, actuando como intérprete e informador ante su condiscípulo el sultán marroquí Muley Xeque cuando éste estuvo en España...), y de-

19 V. el apasionante epistolario de Clénard en Roersch, A., La correspondance de Nicolas Clénard, 3 vols., Bruxelles, 1941, passim.

${ }^{20}$ BAtaillon, M., «L'arabe à Salamanque au temps de la Renaissance», Hespéris (París) 21 (1935), 1-17.

${ }^{21} I d ., 17$.

${ }^{22}$ Estas noticias se encuentran en Archivo Histórico Nacional, Universidades, libro 1128-F, f. $24 \mathrm{v}$ y ss. Para más detalle, v. Rodríguez Mediano, F. y García-Arenal, M., «De Diego de Urrea a Marcos Dobelio». 
bió de descuidar sus clases durante algunas temporadas. Aun así, pudo formar algunos discípulos (volveré luego sobre uno de ellos), y reunir una serie de libros árabes cuyos títulos y procedencia, de momento, desconozco. El episodio es interesante, pues se trata de uno de los escasos momentos en los que la enseñanza del árabe pudo institucionalizarse en las universidades españolas en esta época.

La figura de Diego de Urrea, sin embargo, no agota la presencia de expertos en estudios árabes en Alcalá en ese momento. Nuestro arabista coincidió en ella con el catedrático de Matemáticas Diego Pérez de Mesa, personalidad inquieta y, al parecer, protagonista de intereses muy diversos más o menos relacionados con su labor profesional como matemático, catedrático en las universidades de Alcalá y Salamanca, y cosmógrafo ${ }^{23}$. Ocupado de cuestiones de pensamiento político, fue el autor de una Política o razón de estado sacada de Aristóteles ${ }^{24}$. Sabemos, además, que Diego Pérez de Mesa sabía árabe; de hecho, su nombre sale alguna vez a colación a propósito del asunto de los Plomos del Sacromonte, cuando el arzobispo d. Pedro de Castro escribió a Italia buscando a expertos en árabe que pudiesen viajar hasta Granada para colaborar en la traducción de los libros. En ese momento, 1608, Pérez de Mesa se encontraba en Roma, y engrosaba la lista de posibles candidatos a traductores de los Plomos, junto con nombres tan importantes para la historia del arabismo y de la imprenta árabe en Europa como el de Giovanni Battista Raimondi ${ }^{25}$. Es posible que Pérez de Mesa aprendiese el árabe con Diego de Urrea durante los años en que ambos coincidieron en Alcalá. Es posible, también, que sus intereses por el árabe estuviesen relacionados con la resolución de ciertos problemas técnicos que sabemos le interesaban. En un texto que escribió como recreación y complemento del Libro de grandezas y cosas notables de España de Pedro de Medina ${ }^{26}$, titulado Primera y segunda parte de la grandeza y cosas notables de España, (Alcalá de Henares, 1595), Diego Pérez de Mesa incluyó un método para realizar la conversión de fechas musulmanas a cristianas, suficientemente riguroso como para corregir los errores que en punto a cronología habían realizado Ambrosio

23 Pérez de Mesa es autor de Los movimientos de la tierra y de los cuerpos celestiales, que se conserva manuscrito, y de unos Comentarios de sphera, publicados en 1596, y en los que realiza una crítica matizada del modelo copernicano, mostrándose contrario a la posibilidad del movimiento de la tierra. V. López PiÑero, J.M., Ciencia y técnica en la sociedad española de los siglos XVI y XVII, Madrid, 1979,184 y 188.

${ }^{24}$ Política o razón de estado. Convivencia y educación democráticas, ed. L. Pereña y C. Baciero, y la colaboración de V. Abril, A. García y F. Maseda, Madrid, CSIC, Escuela Española de la Paz, Corpus Hispaniorum de Pace, vol. XX, 1980.

25 Archivo de la Abadía del Sacromonte, Legajo VI, f. 1191. Usamos este documento y estas referencias en Rodríguez Mediano, F. y GArcía-Arenal, M., «De Diego de Urrea a Marcos Dobelio».

${ }^{26}$ La obra de Pedro de Medina está editada por GonZÁlez PalenCiA, Á., Obras de Pedro de Medina, Madrid, 1944. 
de Morales y Luis del Mármol27. La de la cronología era una cuestión muy importante desde la Edad Media, cuyo estudio alcanzó un notable apogeo durante el Renacimiento. Más que el árido campo de experimentación de una técnica más o menos útil, la cronología constituía un modo privilegiado de considerar la posición del mundo dentro de un universo nuevamente entrevisto, y la del hombre dentro de un transcurrir histórico poseído, a menudo, por un sentido providencialista; era algo "esencial a la vida civilizada», que dotaba al pasado humano de «orden y coherencia» ${ }^{28}$. A ello hay que añadir, además, preocupaciones circunstanciales, pero de extrema importancia en esta época, como la reforma del calendario juliano impulsada por el papado, y culminada por Gregorio XIII, que supuso la dedicación de muchos matemáticos a este tema. La aproximación a los graves asuntos abiertos por la cronología se realizaba desde una perspectiva compleja, a la vez técnico-matemática e historiográfica, como puede apreciarse en el tema de la correcta transformación de las fechas de la hégira a las de la era cristiana. Este asunto, recurrente en la historiografía española desde la Edad Media hasta fechas muy recientes ${ }^{29}$, implicaba en general la cuestión de las relaciones entre cristianos y musulmanes y el de las vías de conocimiento entre ambas culturas. Así, el marqués de Mondéjar, criticando que el Padre Moret escribiese en sus Anales del reino de Pamplona que los autores árabes no tenían conformidad entre sí a la hora de contar sus años, afirmaba que el problema era en realidad de los españoles, que habían perdido la costumbre de tratar con los musulmanes ${ }^{30}$. Así, «el Padre Moret y los autores an perdido el tiempo en disputar sobre una cosa incontestable y en que los Moros Africanos sus vecinos los ubieran ynstruido si ubieran querido informarse de la verdad del caso»31; por el contrario, «antes los christianos no an savido las costumbres de las cosas de los árabes» ${ }^{32}$. Este argumento crítico hacia una historiografía española poco preocupada por conocer realmente a unos pueblos que estaban a su lado se repite con cierta frecuencia. Así, ya a comienzos del s. XIX, el padre Martín Benedito, en el frontispicio de su obra dedicada a este mismo asunto, afirmaba que «la ignorancia de nuestros historiadores es esta parte es también tanto más indecorosa, quanto ellos tuvieron más ocasión de oír y tratar a los mismos Árabes, y otros de manejar, examinar y confrontar sus escritos, que los de otras naciones. Que los extrangeros no hayan hallado hasta

\footnotetext{
27 PÉREZ DE MESA, Diego, Primera y segunda parte de la grandeza y cosas notables de España (...), Alcalá de Henares, 1595, primera parte, capítulo XVII.

${ }^{28}$ Grafton, A., Joseph Scaliger. A Study in the History of Classical Scholarship. II.- Historical Chronology, Oxford, 1993, 13 y passim.

29 Además de los autores citados, historiadores y científicos interesados en la cuestión de la cronología musulmana, se podrían citar otros tan significativos como Mariana, y su De annis arabum.

30 MONDÉJAR, Marqués de, Disertazion sobre el año y dia en que comenzo la ejira o la hepocha de los Arabes y de los Mahometanos, BNM, Mss. 2288, f. 1v.

${ }^{31} I d .$, f. $3 \mathrm{v}$.

${ }^{32} I d$., f. $11 \mathrm{v}$.
} 
ahora regla general y segura para reducir los años lunares mahometanos a solares civiles christianos es cosa que causa admiración; pero es más de admirar que nuestros españoles, que pudieron oír y aprender la cuenta Mahometana, nos hayan dexado en tinieblas por no avernos dado esta ilustración cronológica» ${ }^{33}$. La afirmación de que los musulmanes contaban con un método sólido y preciso de medición del tiempo era algo más que una simple curiosidad: se trataba de un logro técnico de alto valor, que demostraba un profundo grado de civilización ${ }^{34}$.

De manera general, en la medida en que estos intereses se vinculaban con el conocimiento de la lengua árabe, algunos eruditos veían confirmada su certeza de que en los libros árabes, contrariamente al prejuicio más o menos extendido, se escondía una gran cantidad de sabiduría que convenía rescatar; y desde luego, la lengua árabe era llave necesaria para acceder a tal tesoro ${ }^{35}$. Ello atañía de manera muy especial a disciplinas como la medicina, campo en el que el Canon de Avicena estaba establecido como autoridad máxima ${ }^{36}$, pero tam-

33 Benedito, Fray Martín, Arte de verificar las fechas Arávigas o Método seguro de reducir los días, meses y años de la cuenta lunar Mahometana a días, meses y años solares, civiles, christianos, BNM, Mss. 1707, f. 11.

34 V., por ejemplo, la admiración de los conquistadores hacia los calendarios aztecas. GRAFTON, A., Joseph Scaliger, 6. En la actualidad estoy comenzando a preparar un trabajo sobre el reducción de las fechas de la hégira a fechas cristianas en la historiografía española de los ss. XVI-XVII.

$35 \mathrm{~V}$., por ejemplo, una alabanza de los sabios árabes en la introducción de William Bedwell a la traducción árabe de las epístolas de S. Juan: «'In re medica, bone Deus, quanta est scriptorum caterva? Memorabo Rhasin, Abin Sennam, Mesuem, Serapionem? quam bonos, quam serios scriptores! Quantum Philosophi uni debent Abin-Rhoi, illis aestimandum relinquo, quibus subtiles Aristotelis minutias rimari curae est. Mathematicis omnium charissimi Arabes: quia Mathematica illis. Has enim artes hi prae caeteris nationibus invenerunt, coluerunt, perfecerunt. Teste mihi Geber, Haly, Thebit, Alphraganus, Albumasar, et alii multi graves et acuti ingenii authores, quorum inventa in his artibus valde celebrantur...», apud Hamilton, Alastair, Arab Culture and Ottoman Magnificence in Antwerp's Golden Age, The Arcadian Library-Oxford University Press, New York, 2001, 110.

36 Son abundantísimas, en estos siglos, las referencias a la importancia de la obra de Avicena, y a la necesidad que muchos médicos sentían de conocer más o menos la lengua árabe para acercarse al Canon. Pero existía también, como reacción, el contratópico de que Avicena no era en realidad tan importante, o de que lo mejor de su conocimiento provenía de la época preislámica. Así, por ejemplo, el propio Pedro de Medina lo expresaba de esta manera: «Desta [Córdoba] fueron aquel excelente poeta Lucano, y Avicena, gran médico, de cuyo nombre se intitula el libro tan señalado en medicina, llamado Avicena. Deste libro dice el bienaventurado San Ilefonso, Arzobispo de Toledo, que el glorioso San Isidro hizo un muy excelente libro de medicina; el cual quedó en su cámara cuando de este siglo pasó, y antes que este libro viniese a poder de ninguna persona que lo conociese, vino de las partes de África a suceder en la Silla Arzobispal de Sevilla un obispo malo, inficionado de la heregía arriana, que se decía Teodosio, Griego de Nación; el cual tomó muchos libros de los que San Isidro había dejado en estudio y entre ellos halló aquel libro de medicina; y porque él tenía necesidad de entender algunos nombres Arábigos, envió por un moro letrado que se lo declarase; que era gran médico y se decía Avicena; y en pago de su trabajo, dióle aquel libro que San Isidro había hecho para que el moro se lo intitulase a sí mismo, como si él lo hubiese compuesto. Afirman muchos que este es el mismo libro que los médicos tienen agora principal, que se nombra Avicena; y dicen que como aquel libro fué entonces trasladado de latín en vulgar (porque el dicho moro que 
bién a otras como la geometría. De ello constituye un buen ejemplo, de nuevo, nuestro Diego de Urrea. Al acercarse la etapa final de su vida y de su carrera, Diego de Urrea se estableció en Italia acompañando al Conde de Lemos, gracias, sin duda, a su amistad con los hermanos Leonardo de Argensola. En Nápoles, Urrea contactó con Giovanni Battista della Porta y, por mediación de éste, con el príncipe Francesco Cesi, que acababa de fundar la Accademia dei Lincei. Cuando se estableció una colonia napolitana de los Lincei, Diego de Urrea entró a formar parte de la misma. Sin entrar en los detalles de un episodio por lo demás interesantísimo, sólo señalaré aquí que Urrea fue en cierto modo una excepción en la composición de la Accademia del Lincei, pues, a diferencia de los demás miembros, él no poseía entrenamiento en filosofía natural. La invitación de Cesi, además de otras consideraciones de tipo político, se debió en parte a que, como arabista, Urrea podía traducir libros necesarios para los trabajos de algunos académicos; en concreto, Galileo esperó que Urrea pudiese traducir algunos libros de las Cónicas de Apolonio, que sólo se habían conservado en su traducción árabe ${ }^{37}$. Urrea no pudo realizar este encargo que Galileo le realizó a través de Francesco Cesi, entre otras cosas porque murió al poco tiempo, probablemente en 1615. Su biografía, sin embargo, me parece extremadamente significativa: desde su itinerario de ida y vuelta entre Italia y el Norte de África, entre el Islam y el cristianismo, que repitieron miles de sus contemporáneos ${ }^{38}$, hasta su trabajo como «arabista», que le hizo ocuparse de algunos de los temas fundamentales en los que el conocimiento del árabe era pertinente en la España y en la Europa de su tiempo: la traducción de los libros plúmbeos del Sacromonte, la catalogación de los manuscritos de El Escorial, las

no sabía latín lo pudiese entender) y él lo compuso en su lengua arábiga, y después fué otra vez tornado a trasladar en latín, como agora está, dicen que en aquellas traslaciones, por no ser bien entendidos los vocablos hubo muchos yerros, los quales hoy día se hallan en el dicho libro; y muchas veces se ha platicado entre los doctores médicos de corregir los dichos errores de Avicena, porque dicen que son muy dañosos, especialmente en los médicos nuevos no esperimentados. Sería bien que se hiciese por evitar los daños que se siguen o pueden seguir a la salud corporal de muchas personas», Libro de grandezas y cosas notables de España, 84. Nótese que, al tiempo que se ponía en duda la autoría de las aportaciones de Avicena, se reclamaba falsamente el origen cordobés del gran médico musulmán, como un timbre de gloria para la ciudad andaluza.

37 Para todo este episodio, v. Rodríguez Mediano, F., «Diego de Urrea en Italia», y las referencias allí incluidas. Para todo lo relacionado con el interés de los Lincei en lenguas orientales resultan imprescindibles los trabajos de GABRIELI, G., Contributi alla storia della Accademia dei Lincei, Roma, 1989; e Il carteggio linceo, Roma, 1996. Hasta donde conozco, todas las referencias posteriores a estos asuntos se remiten a estos hermosos trabajos de Gabrieli.

${ }^{38} \mathrm{La}$ referencia más conocida es, desde luego, Bennassar, B. y Bennassar, L., Les Chrétiens d'Allah. L'histoire extraordinaire des renégats (XVIe et XVIIe siècles), Paris, 1989, que proporciona un panorama general de un fenómeno realmente importante en todo el Mediterráneo. Para cuestiones más complejas en torno a todo el problema de las conversiones, v., por ejemplo, GARCíA-ARENAL, M., (dir.), Conversions Islamiques. Identités religieuses en Islam méditerranéen, París, Maisonneuve et Larose/European Science Foundation, 2001, y todas las referencias que allí se recogen, y que abarcan una gran cantidad de casos concretos. 
labores de interpretación en lo relativo a las relaciones con Marruecos, la redacción de libros de historia basados en fuentes árabes genuinas, y la traducción de obras científicas y técnicas árabes. A ello se añade, además, su paso por la Universidad de Alcalá de Henares, que constituye uno de los escasos intentos de institucionalización de la enseñanza del árabe en la España de los ss. XVI y XVII.

Entre quienes se interesaban por la lengua y los libros árabes y orientales se repetía con frecuencia que existía una gran cantidad de conocimiento contenido en ellos, escondido tras el velo de la lengua árabe. Una de esas afirmaciones se encuentra en el prólogo que Francisco Gurmendi escribió para su Doctrina phísica y moral de principes, y que dice: «con gusto me ocupé en la traduzión destas sentencias, poniendolas en estilo y lenguaje que gozassen dellas nuestros cortesanos y ciudadanos estudiosos, para que se advierta y note, que tesoros estan escondidos debaxo de aquel idioma Arabe, y para satisfazer a los que ponen en questión si ay libros y Filósofos entre aquellos infieles, porque saque de aquí el dolerse dellos, y pedir a Dios, que es la verdadera sabiduria, los traiga en conocimiento de la verdad»39. La obra de Gurmendi se presenta, pues, como una traducción de «sentencias» políticas arábigas puestas al estilo de los cortesanos y estudiosos españoles, para que éstos pudiesen acercarse a los «tesoros escondidos» en lengua árabe. La afirmación de la existencia de un tal tesoro se realiza, pues, a la par que la de una distancia entre dos mundos que sólo puede recorrerse por obra de una adaptación. En esta idea abundan, por ejemplo, los sonetos colocados en el frontispicio de la obra; Doña Beatriz de Villanueva escoge la metáfora de la abeja que transforma «la amarga retama» en «almíbar»: «Vuestra filosofía trasladada, / del origen Arábigo en Castilla, / buelve cortés el bárbaro idioma. / Flor amarga en miel pura transformada, / por dar al mundo octava maravilla, / que es Gurmendi en Madrid un Tulio en Roma» ${ }^{40}$. Que tal adaptación existe lo demuestra el estilo de Gurmendi, bastante alejado de ese aire un poco extraño de contrahacimiento sintáctico propio de las traducciones rápidas y superficiales del árabe. El resultado es, también un poco extraño: un espejo de príncipes dirigido al Duque de Lerma, pero traducido del árabe, y conteniendo ejemplos sacados de la historia y la literatura árabomusulmanas.

La figura de Gurmendi es ya conocida, y su actividad como autor del libro citado, como intérprete de árabe y también, cómo no, traductor de los Plomos

39 Gurmend, Francisco de, Doctrina phisica y moral de principes. Dirigido a don Francisco Gomez Sandoval y Roxas, Duque de Lerma (...). Traduzido de arabigo en castellano, por Francisco de Gurmendi, criado de Su Magestad, natural de la Provincia de Guipuzcoa, Madrid, 1615.

${ }^{40}$ Otro soneto compuesto para ocasión por d. Juan de Persia es más explícito en cuanto al valor original de esa sabiduría escondida en los libros árabes traducidos por Gurmendi: «De las minas de Arabia en quien se cria / el mas noble metal, otra riqueza / a España ofreces de mayor belleza, / sol que puede alumbrar su Monarquia. / La luz destos escritos es la guia, / O ingenioso Gurmendi, que a la alteza / de los Reyes con gala y agudeza / enseña mejor filosofia». 
del Sacromonte. De origen gipuzcoano ${ }^{41}$, y deudo de d. Juan de Idiáquez, Gurmendi estudió árabe en Madrid, seguramente con Diego de Urrea. Nombrado intéprete de árabe y de lenguas orientales de Felipe III, Gurmendi trabajó en los manuscritos árabes que fueron capturados en 1611 al sultán marroquí Muley Zidán y que acabaron incorporados a la Biblioteca de El Escorial. Como queda dicho, Gurmendi se ocupó también de la traducción de los libros plúmbeos y, como otros traductores, acabó enfrentándose a la Iglesia de Granada a propósito de la autenticidad de los mismos, y ganándose la enemiga de d. Pedro de Castro ${ }^{42}$. Sus críticas se plasmaron en dos libelos, escritos en 1615 y 1617 respectivamente, y que recibieron su correspondiente respuesta por parte de los laminarios cercanos al Arzobispo de Granada. G. Magnier ${ }^{43}$ ha estudiado la más importante de estas dos obras, el Libelo segundo, dentro del marco más general del círculo de Pedro de Valencia, al que también pertenecía Gurmendi, y a quien debemos algunas de las críticas más agudas e interesantes contra la autenticidad los libros. Además de en estos dos libelos, las críticas de Gurmendi a los libros se encuentran en el propio texto de la traducción que realizó de los libros Fundamentum Ecclessiae y De essentia Dei. Allí, en las anotaciones a los márgenes de la traducción, se encuentran algunos de los argumentos técnicos emplados por el arabista, especialmente que el lenguaje de los libros plúmbeos era un «árabe corrupto», cercano, si no similar, al que hablaban los moriscos de Granada, y por lo tanto moderno ${ }^{44}$, y que estaba repleto de citas y de doctrina coránica ${ }^{45}$. Ante estas críticas, el arzobispo de Granada respondió de forma abrupta en un impreso en el que se contestaban una por una las críticas de Gurmendi. Así, se citaba en él al médico morisco Miguel de Luna (que fue, como se ha dicho, uno de los primeros traductores de los libros, y quizás uno de sus autores materiales), que decía: «que [los libros] tienen mucha antigüedad. Que en la manera y frasis de hablar, son muy diferentes de los Árabes

41 Para estos datos, v. Magnier, G., «Pedro de Valencia, Francisco de Gurmendi and the Plomos de Granada», Al-Qanțara (Madrid) 24 (2003), 409-426.

$42 \mathrm{~V}$, por ejemplo, la valoración del Arzobispo a propósito del trabajo de Grumendi sobre los Plomos: « $\mathrm{Fr}^{\mathrm{co}}$. de Gurmendi presume que entiende la lengua, pero el Arçobispo lo puede recusar porque se trata de qualificar su traduçión y sus notas, y porque apasionadamente se a declarado contra los libros, no deve ser admitido por juez en neg ${ }^{\circ}$. en que se a mostrado parte», Archivo de la Abadía del Sacromonte. Legajo V, f. 843.

43 Ibid.

44 «La primera palabra es morisca, a lo menos lo parece, según como este hombre se lo oyó pronunciar a los Moriscos de Gr. ${ }^{\text {da }}$ [...], demás de que d. ${ }^{\text {do }}$ se quisiera negar que este lenguaje era morisco, por lo menos no es buen Arábigo sino corrupto», Archivo de la Abadía del Sacromonte, Legajo VI, $2^{\underline{a}}$ parte, f. $1137 \mathrm{r}$; «todo esto es lenguaje morisco y lleno de mil solecismos», id., f. 1138v.

45 Por ejemplo: «aquí donde dize que fue Jesús su intercessor y abogado como hombre y no como Dios parece que alude a lo que trae el Alcorán [...]», id., f. 1138r; "y más abaxo donde dize que fue criado Jesús en madre y sin padre parece que son aquellas palabras de Ebueleit el Semarcandi intérprete y expositor del Alcorán [...]», ibid. Nótese la erudición de la cita del teólogo hanafí del s. X Abū l-Layt al-Samarqandī. 
modernos, del tiempo de la secta Mahometana acá: y da las razones, y dize que esto mesmo dirá, y entenderá assí qualquiera, que supiere la lengua Árabe. Y que ay diferencia entre los libros, y los Árabes modernos, como del cielo a la tierra: y que no ay comparación; y que no tienen vocales: y en algunas partes les faltan puntos sustanciales de las letras. Que la letra no es usada por nadie muchos años a. Y que tienen muchas diciones, y términos antiguos, que no los a visto en ningún autor moderno, escripto de seyscientos años acá $[\ldots ..]{ }^{46}$. De todas formas, y ante los evidentes problemas que tal argumentación causaba, el impreso concluía de manera tajante: «No bastaría, ni importaría, que fuesse lengua Morisca, o peregrina: sino mostrase el Intérprete, que la doctrina no es buena. Lo que importara es que sea Christiano: que crea el Credo y doctrina Christiana: y dígale en qualquier lengua, Arábiga, pura o corrupta, o Vizcaýna. Su Sanctidad a hecho la professión de la Fe en lengua Árabe para los Orientales. Pensamos que será muy elegante. No está la fuerça en la lengua: lo que importa es la doctrina, que sea Cathólica y sancta» ${ }^{47}$.

Se ha señalado alguna vez la posibilidad de que la traducción de libros árabes que Gurmendi decía haber realizado en su Doctrina phísica y moral de principes no fuese más que un recurso narrativo al estilo del que vimos utilizó Miguel de Luna en su Verdadera Historia, y sobre el que luego ironizó Cervantes en el Quijote $^{48}$. Sin embargo, los personajes y lugares citados en su libro son bien conocidos dentro de la historia y la tradición literarias árabo-musulmanas, aunque hasta ahora no se han indicado las fuentes en que Gurmendi pudo haberse basado para componer su libro. Sabemos, por ejemplo, que después de la captura, por parte de tres bajeles españoles, de la amplia biblioteca de Muley Zidán en mayo de 1612, Gurmendi pidió «se le dejen algunos libros de todas las facultades y ciencias, que él tuviese por necesarios para sus estudios de la dicha lengua arábiga, como son los vocabularios y otros de la propiedad y elegancia de la lengua: y el dicho Gurmendi podrá traducir en castellano algunos que parezcan merecerlo, por ser materias morales ó de historia» ${ }^{49}$. Parece, pues, que su Doctrina es el resultado de este impulso inicial. Aún no disponemos ni de una edición moderna de esta obra, ni de un análisis detallado de sus fuentes que nos ilustre sobre la manera de trabajar de Gurmendi ${ }^{50}$. A la espera de ese trabajo, sí se pueden avanzar algunos hechos. Los personajes citados por Gurmendi para ilustrar su discurso pertenecen a una antigua tradición de literatura

\footnotetext{
46 Papeles varios del Sacro Monte, BNE Mss. 6437, f. 26v. El compañero de Luna, Alonso del Castillo, aseveraba estos argumentos diciendo que el árabe usado en los libros era anterior a Mahoma.

${ }^{47} I d$., f. $28 \mathrm{v}$.

48 Tal era, por ejemplo, la pregunta que se hacía J.A. Maravall. V. MAgnier, G., «Pedro de Valencia, Francisco de Gurmendi and the Plomos de Granada», 415.

${ }_{49}$ Carta de Francisco Gurmendi a Gregorio de Ciriza, Madrid, 6 de mayo de 1614, citado en Justel, Braulio, La Real Biblioteca de El Escorial y sus manuscritos árabes. Sinopsis histórico-descriptiva, Madrid, 1978, 181-3.

${ }^{50}$ En la actualidad, Isabel Llopis Mena está realizando en la Universidad de Alicante una Tesis Doctoral que cubrirá ambas lagunas.
} 
política y de espejos de príncipes en la literatura árabo-musulmana, que recurre a tradiciones, dichos o anécdotas atribuidos a personajes como Cosroes, Anushirvan, Bahram, el califa al-Manșūr, su hijo al-Mahdī, 'Umar b. 'Abd al-'Azīz, etc. Esta literatura se nutre, por supuesto, de la tradición islámica, pero también de otras tradiciones preislámicas, persas o indias. De hecho, «la sabia Hind» que aparece citada como un personaje en la Doctrina de Gurmendi se refiere en realidad a la India (Hind en árabe) ${ }^{51}$, cuyos sabios y libros aparecen citados en obras como Kalila y Dimna o, sobre todo, la Lámpara de los Príncipes (Sirâŷy al-mulūk) de al-Țurțūšs ${ }^{52}$. Un estudio mostrará, creo, las coincidencias de la Doctrina de Gurmendi con esta última obra, y también con la Nașìhat almulūk, escrita por el celebérrimo filósofo y teólogo Algacel. Un solo ejemplo podrá bastar aquí para ilustrar esta semejanza. Gurmendi cuenta, por ejemplo, que «escribió un Emperador de Roma a Cosdrue, Rey de Persia, preguntándole con qué tenía y conservaba en paz su Reyno, y respondióle: con no afloxar y desfallecer en lo que mando y prohíbo" ${ }^{53}$. Este pasaje puede compararse con el siguiente, extraído del citado texto de Algazel: «A letter reached Anūshīrvān from the Caesar of the Romans, asking 'Wherein lies the stability of the King's rule?' Anūshīrvān wrote in reply: 'I never issue orders thoughtlessly, and when I issue orders, I carry them out. I never leave behind hope or fear; that is to say, if I give cause for hope, I fulfil it, and if I give cause for fear, I do not shrink from doing what I have said» ${ }^{54}$.

Marcos Dobelio Citeroni es otro de los personajes que trabajó en la traducción de los Libros plúmbeos. Su biografía no es menos fascinante que la del ya citado Diego de Urrea. Dobelio era un cristiano oriental de origen kurdo, que enseñó árabe en La Sapienza de Roma entre 1606 y 1610. Cuando el arzobispo d. Pedro de Castro buscó traductores de árabe en Italia para que trabajasen sobre los Plomos ${ }^{55}$, el nombre de Marcos Dobelio o al-Du ābilī surgió entre otros muchos, y acabó finalmente viniendo a España, donde se estableción ${ }^{56}$. Como le ocurrió a otros traductores, Diego de Urrea y Gurmendi entre ellos, Dobelio acabó enfrentado a d. Pedro de Castro, pues él se dio cuenta de la fal-

51 Agradezco a Maribel Fierro que llamase mi atención sobre esta identificación, y en general, sus indicaciones sobre las posibles fuentes de Gurmendi.

52 Existe una traducción española de este libro, obra de Maximiliano Alarcón: ABUBÉQUER DE TORTOSA, Lámpara de los príncipes, 2 vols., Madrid, 1930-1.

53 GuRMendi, F., Doctrina, libro II, cap. 3.

${ }^{4}$ BAgley, F.R.C., Ghazālì's book Counsel for Kings, Oxford University Press, Londres-Nueva York-Toronto, $2^{\text {a }}$ ed., 1971, 73. Se trata de una traducción del texto persa.

55 Algunos documentos del Archivo de la Abadía del Sacromonte tratan de manera más detallada esta búsqueda, por parte de d. Pedro de Castro, de traductores de árabe en Italia. Uno de los nombres que llegó a proponerse fue el del propio Giovanni Battista Raimondi, el gran orientalista que trabajó en la Tipografia Medicea Orientale. Citamos estos docs. en Rodríguez MEDIANO, F. y García-Arenal, M., «De Diego de Urrea a Marcos Dobelio».

56 El estudio más detallado que existe hasta ahora sobre las actividades de Dobelio en España es MOROCHO, Gaspar, "Estudio Introductorio» a El discurso sobre el pergamino y las láminas de Granada, en Valencia, Pedro de, Obras Completas, León, 1999, IV, 307 y ss. 
sedad de los libros porque «ni el estilo, frases, lengua ni caracteres, correspondía con ningún autor Árabe christiano ni mahometano, porque antes que Mahoma predicase su falsa seta huvo en el oriente y medio día Christianos y hombres doctos, y echó de ver que el autor de las dichas láminas era algún morisco ygnorante ${ }^{57}$. La argumentación acerca de las características del árabe de los Plomos reproduce, como se ve, parte de las críticas que Gurmendi había realizado. En todo caso, una argumentación in extenso de su postura ante los Plomos se encuentra en una obra suya, titulada Nuevo descubrimiento de la falsedad del metal, texto fascinante que está siendo en la actualidad objeto de un estudio detallado por parte de Maylene Cotto Andino ${ }^{58}$. Como se ha visto, otra de las obras de Dobelio se titulaba Suma que trata del tiempo cuando los mabometanos ganaron a África, y cómo después pasaron a España... vuelta de arábigo en romances9, obra que hasta ahora se creía perdida, y sobre la que volveré más adelante. Pero aún hay otros rastros de la actividad arabista de Marco Dobelio Citeroni. Un manuscrito de la Biblioteca Nacional de Madrid se titula Libro yntitulado las Margaritas cogida (sic), donde se trata de los remedios experimentados curiosos y fáçiles de gran provecho y poca costa con todos los remedios del començando desde la planta de la caveça hasta llegar a las plantas de los pies. Compuesto por el Doctorísimo Philósopho y Phísico y singular hombre único en su tiempo Abbuferquer Mabomed. Derixido al muy poderoso señor, amigo de los savios y de la saviduría, el Rey David hijo del Rey Almodfer señor de Amano ${ }^{60}$. Este libro se presenta como «traduzido de Arávigo en lengua castellana por Marcos Aurelio Citerón, hombre muy doctto y experimentado en los secrettos de natura, grande Istorio e intérprete de la lengua aráviga del Rey Don Feliphe [sic] quarto nuestro Señor, que Dios guarde largos y felices años y a todos sus fieles vasallos» ${ }^{61}$. No parece muy difícil identificar a este «Marcos Aurelio Citeron» con el Marcos Dobelio Citeroni al que me estoy refiriendo. Tal atribución, además de corregir la del propio manuscrito (seguramente, una copia de la traducción original, a juzgar por los errores de transcripción), ampliaría el número de las obras que conocemos de este interesante personaje.

Marcos Dobelio, pues, como Gurmendi, como tantos otros traductores y eruditos de su tiempo, se vio envuelto en una dura polémica cuando expresó sus dudas sobre la autenticidad del texto de los plomos. Esa polémica no se limitaba al terreno de los argumentos filológicos, históricos o literarios, sino que llegaba a veces a los ataques personales, como ocurrió, por ejemplo, en el

57 Archivo General de Simancas, Estado, Leg. 2645. Citado en Rodríguez Mediano, F. y García-Arenal, M., «Diego de Urrea».

${ }^{58}$ Para G. Morocho, este texto "podría ser uno de los monumentos de la Orientalística española, durante la primera mitad del s. XVII», v. «Estudio Introductorio», 312.

59 Habla de ella Monroe, J.T., Islam and the Arabs, 23, citando a Menéndez Pelayo, M., La ciencia española, ed. Enrique Sánchez Reyes, 3 vols. Santander, 1954, vol. III, 124.

${ }^{60}$ BNE, Mss. 2021. La obra se encuentra a partir del f. 32r.

${ }^{61} \mathrm{Id} ., 32 \mathrm{v}$. 
caso del padre Ignacio de las Casas ${ }^{62}$. Esa inquina personal está quizás reflejada en este comentario: «Dicen que murió Marcos de Obeli, no e savido quándo ni dónde ni si quedaron dél algunos libros o papeles, y si uviese sido en alguna taberna y los gastasen en papelillos de tabaco, tendrían su merecido; aunque algo podría aver quedado que nos fuese de importancia ver, y realmente el hombre, aunque de malas costumbres y peor intención, era entendido y noticioso de la lengua Arábiga, áyale Dios dado buena muerte y la luz que avía menester para salvarse [...]». Esta frase se encuentra en una carta dirigida por el Marqués de Estepa al canónigo Martín Vázquez Siruela el 11 de febrero de 165463. A pesar de la evidente enemistad que la carta manifiesta, pervive en ella el reconocimiento a las calidades de Dobelio como arabista, que debieron ser notables. Dos años antes, por ejemplo, Juan Bautista Centurión escribía también a Vázquez Siruela: "Holgaré mucho me embíe Vuestra Merced el papel de Marcos De Obeli para verle. No dudo de que estará bien traducido, porque es ábil y inteligente en la lengua Árabe» ${ }^{64}$. Sea como fuere, Vázquez Siruela tenía un interés especial en algún libro o documento que se encontraba entre los papeles de Dobelio, pues estuvo haciendo gestiones para encontrarlo a la muerte de éste. Así, en 1656, Nicolás Antonio le escribía: "Yo hize la diligencia posible por descubrir noticia de Marcos Obeli, quando ofrecí a Vuestra Merced el hazerla: i quiçá porque della no resultó cosa que pudiese descansar a Vuestra Merced, no se lo escriví. Encontré persona mui suia que le conoçía mucho y comunicava, i me asegura que era tal el desorden con que vivía el buen hombre que no puede saber quién se llevó todo lo que avía en casa, que sería bien poco, o nada. Y este libro avrá parado en lo que otros que no se entienden. Hablé al intérprete que es oy de la lengua Arábiga y Turca, que es un Ragusés llamado Vincencio Bratuti, por ver si avía llegado a su poder el libro, y lo le a visto, ni le conoçe» ${ }^{65}$. Este Vicente Bratuti fue, en efecto, intérprete de lenguas orientales del emperador Fernando III de Alemania, y después de Felipe $\mathrm{IV}^{66}$, y autor de varias traducciones del turco al castellano: una versión turca

${ }^{62} \mathrm{~V}$, por ejemplo, Benítez SÁncheZ-Blanco, R., «De Pablo a Saulo: traducción, crítica y denuncia de los libros plúmbeos por el P. Ignacio de las Casas, S.J.», Al-Qantara (Madrid) 23 (2002), 403-436.

63 Papeles varios de Martín Vázquez Siruela, Real Biblioteca de Palacio, mss. II/158, f. 153r. Las cartas, contenidas en este manuscrito, enviadas por Nicolás Antonio a Vázquez Siruela, han sido ya tratadas por JAMmes, Robert y GORSSE, Odette, «Nicolás Antonio et le combat pour la vérité (31 lettres de Nicolás Antonio à Vázquez Siruela)», en Hommage des Hispanistes français à Noël Salomon, Barcelona, 1979, 411-429, sobre todo desde el punto de vista de la crítica a los falsos cronicones.

${ }^{64}$ Carta de Juan Bautista Centurión al M. Vázquez Siruela, Estepa, 3 de julio de 1652, Papeles varios de Martín Vázquez Siruela, Real Biblioteca de Palacio, mss. citado, f. 154r.

65 Carta de Nicolás Antonio a M. Vázquez Siruela, Madrid, 5 de diciembre de 1656, id., f. $104 \mathrm{v}$.

66 Pellicer y SAFOrCADA, Juan Antonio, Ensayo de una bibliotheca de traductores españoles, donde se da noticia de las traducciones que hay en castellano de la Sagrada Escritura (...), Madrid, 1778, ed. facsímil, Badajoz, 2002, 166-7. V., sobre este autor y esta obra, CEBRIÁN, José, Nicolás Antonio y la Ilustración española, Kassel, 1997, 193. 
del Kalila y Dimna ${ }^{67}$ que tituló Espejo político y moral para príncipes, ministros y todo género de personas, y una obra del historiador otomano del s. XVI Celalzade Mustafa Çelebi, con el título de Anales de Egipto ${ }^{68}$. Lo que no resulta tan fácil de identificar es cuál podía ser el libro que Vázquez Siruela buscaba entre los papeles de Dobelio. En la misma carta, a continuación del texto citado, Nicolás Antonio añadía «Si Vuestra Merced quiere comunicar en toda confiança el secreto que dize del nombre geográfico que se avía de buscar en la Historia de Ismael, podrá apuntarlo para que io haga alguna diligencia con los que huviere aquí diestros (si ay algunos) en esta lengua Arábiga». Esta Historia de Ismail a la que se refiere Nicolás Antonio es el Mujtașar ta'rīj al-bašar del príncipe sirio Abū l-Fidā Ismāêll, una gruesa obra que constituye un resumen de la historia del Islam hasta el año 747 de la hégira. En el mss. 6156 de la Biblioteca Nacional de Madrid, que contiene numerosos papeles de Vázquez Siruela, hay un fragmento de una traducción de una crónica árabe, en cuyo margen aparece la anotación «Ismael Rey de Amano en la Suma Universal de las Corónicas» ${ }^{69}$. Este fragmento, que ocupa un par de páginas y trata «de la forma de toga que solía el Califa enbiar a los Reyes: quien los declarava verdaderos reyes y los confirmava», es en efecto la traducción de un pasaje del $T a{ }^{\prime} r \bar{j} j$ de $A b \bar{u}$ l-Fidā $\bar{a}^{70}$. Pero éste no es el único ejemplo que tenemos del interés en España por la obra de Abū l-Fidā. Es Casiri quien nos da la noticia de que Marcos Dobelio había realizado la traducción de algunos pasajes de esta obra, y una sinopsis de la misma, cuyo manuscrito poseía Campomanes ${ }^{71}$. En efecto, entre los papeles de Campomanes figura una Suma que trata del tiempo quando los mabometanos ganaron a África, y cómo después pasaron a España, y de las guerras que en la dicha Provincia tuvieron con los Christianos, y de otros succesos en varias partes del mundo mui útiles y curiosas. Sacada de la Suma universal de las Chrónicas de Amadeddin Abumabamed

67 Para Pellicer y Saforcada, se notaba que la traducción de Bratuti era del Turco, lengua dada a la prolijidad; al ser demasiado literal, Bratuti había adoptado «el estilo estrañamente metaforico de la lengua Turca, y asi ocurren con frequencia estas y otras expresiones: Morder el dedo del espanto con el diente de la admiracion. Arañar la cara de la lealtad con la uña de la traycion. Acometer a un corazon el exercito de la pesadumbre. Apagarse el canail [sic, por candil] de la tranquilidad. El fuego de la hambre echó al viento la era de la paciencia.», Ensayo, 167.

68 Anales de Egipto, en que se trata de las cosas más principales que han sucedido desde el principio del mundo basta de cien años a esta parte. Compuestos por Salib Gelil, historiador turco, y aora traducidos de lengua turca en castellana por don Vicente Bratuti, Ragusés, traductor de lenguas de Carlos Segundo el Grande (...), Madrid, Melchor Álvarez, 1678. El volumen incluye también unas «sentencias filosóficas, compuestas por un doctor persa, llamado Seaid, y aora traducidas de lengua persiana en castellana por el mismo d. Vicente Bratuti», id., 345. Agradezco a Miguel Ángel de Bunes el que me haya confirmado que la identificación de Mustafa Çelebi como el autor de la fuente original turca que tradujo Bratuti es correcta.

69 Debajo de un «Rasis el moro» que aparece tachado. Papeles varios. Del señor Conde de Miranda, BNM, mss. 6156, f. 82r.

${ }_{70}$ V. ABŪ L-FIDĀ, Mujtașar al-ta'rīj, 4 vols. en 2 tomos, s.l., s.a., III, 114.

71 CASIRI, M., Bibliotheca Arabico-Hispana Escurialensis, II, 15. V. «Diego de Urrea en Italia», 197. 
Almayad Ismael, Rey de Amano, chronista docto y célebre, por Marco de Obelio Citeroni, y buelta de arábigo en romance por él mismo. Con las anotaciones a la margen de el mismo Intérprete ${ }^{72}$. Como se ve, se trata de la misma obra que Monroe había dado por perdida, y que señalaba como uno de los pocos ejemplos del interés por los estudios árabes en la España del s. XVII. A falta de una comprobación más detallada, se trata de una traducción parcial del Ta'rìj de Abū l-Fidā. Esta crónica, de la que existe un manuscrito en El Escorial ${ }^{73}$, fue conocida en Europa desde fecha temprana, convirtiéndose en una de las obras de referencia del orientalismo europeo del s. XVIII ${ }^{74}$. La traducción de Dobelio presenta así, en gran medida, un cáracter pionero, no sólo en España, sino en toda Europa, donde el texto de Abū l-Fidā no fue traducido y apreciado hasta algunas décadas más tarde. Una nota del propio Campomanes en el primer folio del manuscrito dice: «me inclino a que esta obra no es íntegra, sino una traducción literal de lo que [del Ta'rỉj de Abū l-Fidā] pertenece a España, o tiene precisa conexión con la historia Ârabe de ella. Su utilidad es tan notoria que no necesita recomendación, como se verá en mi Chronología Árabe [.... ». Esta obra de Campomanes, en efecto, se presentaba como un nuevo intento, además de los ya reseñados aquí, de integrar, por la vía de la cronología, la historia de al-Andalus en la historia de España; para ello, la existencia de una importante crónica árabe traducida al español constituía, sin duda, un material de primera importancia ${ }^{75}$.

Los proyectos de Martín Vázquez Siruela solían quedar inacabados ${ }^{76}$, y de hecho sus múltiples escritos, nunca editados, se encuentran dispersos en un grado más o menos avanzado de elaboración ${ }^{77}$. Sin entrar con profundidad en todos ellos, sí me interesa señalar que en Vázquez Siruela confluyen dos circunstancias significativas para mi argumentación: una es su vinculación al Sacromonte, y la otra su condición de anticuario e historiador. Vázquez Siruela

72 Cejudo López, J., Catálogo del Archivo del Conde de Campomanes (fondos Carmen Dorado y Rafael Gasset), Madrid, 1975, 18-19. La referencia del mss. es 4-1.

${ }_{73}$ Mss. árabe 1641, LÉVI-ProvenÇAL, É., Les manuscrits arabes de l'Escurial décrits d'après les notes de Hartwig Derembourg (...) revues et mises à jour par..., t. III, París, 1928, 179. El manuscrito formaba parte de los robados a Muley Zidán.

${ }^{74}$ GibB, H.A.R., «Abū l-Fidā», The Enciclopaedia of Islam (New Edition) (EI'), Leiden, vol. I, 118b-119b. SCHNurrer, Ch. F. de, Bibliotheca Arabica, Halle, 1811, reimp. Amsterdan 1968, 117 y ss.

75 En breve espero poder editar el texto de esta importante y pionera traducción de Dobelio.

76 Nicolás Antonio dice que Vázquez Siruela era "íntimo amigo mío en vida, lo elogié lo más parca y modestamente que pude como si hablase de mis cosas. Este varón eruditísmo examinó muchas cosas, volvió sus ojos a las adversidades, lo retuvo todo en su memoria; concluyó pocas cosas, como que solía casi siempre lo que se le ofrecía ocasionalmente, examinarlo superficialmente y como de pasada, por lo que muchas cosas comenzadas quedaron en sus fichas», ANTONIO, Nicolás, Biblioteca Hispana Nueva, trad. Miguel Matilla Martínez, Madrid, 1999, II, 137.

77 V. Gallego Morell, Antonio, «Algunas noticias sobre don Martín Vázquez Siruela», en Estudios dedicados a Menéndez Pidal, t. IV, Madrid, 1953, 405-424; ALONSO, Dámaso, "Todos contra Pellicer», Revista de Filología Española (Madrid) 24 (1937), 320-342, 326. 
fue canónigo de la Abadía del Sacromonte, y después racionero de la Catedral de Sevilla. Ferviente defensor de la autenticidad de los Libros Plúmbeos, existe una significativa documentación que muestra el papel fundamental que tuvo, en primer lugar, para tratar de impedir que los Libros Plúmbeos fuesen llevados a Madrid y luego a Roma. Más tarde, mantiene una correspondencia continuada con los enviados granadinos a Roma, encargados de defender ante el papa la causa de los Libros; en ella le vemos siguiendo muy de cerca toda la historia del traslado de los libros a Roma, y siendo informado con todo detalle de las gestiones emprendidas por los enviados granadinos ante el Papa para defender su autenticidad: de cómo, por ejemplo, éstos encontraron a fray Bartolomé de Pectorano, quien, tras un primer momento de escepticismo, acabó realizando una traducción latina de los libros, inspirado por el Espíritu Santo ${ }^{78}$. Por otro lado, su epistolario con Adán Centurión, Marqués de Estepa, muestra cómo éste comentaba con Vázquez Siruela algunos lugares de su propia traducción de los Plomos ${ }^{79}$. En estos y otros ejemplos queda claro que el afán por comprender el contenido de los Libros Plúmbeos estaba relacionado con el interés que Vázquez Siruela (y otros contemporáneos suyos, como veremos) tenía por la lengua árabe. Pero de los Plomos se desprendía un interés historiográfico más amplio, si cabe. No es un azar si las primeras historias de Granada impresas aparecieron después del descubrimiento de los Plomos: éstos permitían toda una reinterpretación de la historia y la arqueología de ciudades como Granada, Córdoba o Sevilla, donde el pasado musulmán y árabe era una evidencia ineludible ${ }^{80}$. Ahora, el árabe, perdida su condición musulmana gracias al extraordinario descubrimiento del Sacromonte, se tornaba la prueba palmaria de la conexión de esos lugares con la historia sagrada del cristianismo. De esta manera, los Plomos se vincularon con el problema historiográfico de los orígenes, tan de boga en la época; y ello con una particularidad: aunque los Plomos compartían ciertas características con otras famosas y sonadas falsificaciones como las de Jerónimo Román de la Higuera, o las antiguas mixtificaciones berosianas introducidas con fuerza en parte de la historiografía española, su carácter sagrado, firmemente apoyado por una parte importante de la Contrarreforma española, se imponía sobre las posibles dudas históricas o arqueológicas. Esta contradicción fue evidente en personas que estaban implicadas en la defensa de

\footnotetext{
78 Papeles varios del Sacro Monte, BNM, mss 6437, f. 70, 97 y ss.

79 Archivo de la Abadía del Sacromonte, legajo I, 1aㅡ parte, f. 1449. La traducción del Marqués de Estepa fue editada por HagerTy, M., Los libros plúmbeos del Sacromonte, Madrid, $2^{\mathrm{a}}$ ed., 1998. V. también Real Biblioteca de Palacio, mss. cit., passim; en carta del 6 de agosto de 1656, por ejemplo, el Marqués de Estepa comenta a Vázquez Siruela su decisión de traducir la palabra árabe nafs por «persona», aun aceptando la conveniencia del término sugerido por Vázquez Siruela, «ipseitas» (ibid., f. 145r).

80 GARCíA-ARENAL, M., «A modo de conclusión: de la autoría morisca a la antiguedad sagrada de Granada, rescatada del Islam», en García-Arenal, M. y Barrios Aguilera, M. (eds.), Los Plomos del Sacromonte: invención y tesoro (en prensa).
} 
los Plomos y, a la vez, en un esfuerzo historiográfico crítico, empeñado en debelar los groseros errores de los falsos cronicones. Así aparece, de forma deslumbrante, en el epistolario de Bernardo de Aldrete con el Arzobispo d. Pedro de Castro, en el que se muestra cómo el primero, que había demostrado que el castellano provenía del latín, tenía que aceptar, por mor de su vinculación con el Arzobispo, la autenticidad de un documento como el pergamino de la Torre Turpiana, que contenía fragmentos escritos en castellano del s. XVI, pero que supuestamente databan del s. I. Tal contradicción sólo se podía solventar, como tuvo que admitir el propio Aldrete, por el recurso a un milagro divino ${ }^{81}$.

También Vázquez Siruela compartía, aunque de manera muy distinta, este ambiente donde la construcción crítica de una historia de los orígenes se mezclaba con las multiples implicaciones de los Libros Plúmbeos. El racionero de la Catedral de Sevilla es también conocido como anticuario, erudito e historiador. Una difundida anécdota evoca en tono jocoso la figura de Vázquez Siruela en este ambiente de descubrimientos arqueológicos, piedras antiquísimas e interpretaciones eruditas. Francisco de Trillo y Figueroa la relata: «Sobre $\left(l_{0}\right)$ que es muy de notar un risible caso que en mi tiempo sucedió en esta insigne ciudad al doctor Siruela Canonigo del Monte Santo, muy presumido de Antigüedades que, a la verdad, no entendía. Tratóse de hacerle una burla en un festejo que se tubo en el carmen de Soto, Academia de esta ciudad en aquel Siglo, y algunos días antes, un Sacristán de San Salbador, que por temporal tenía también su nicho en fábrica tan hermosa, abrió cinco $S$ en un ladrillo mazarí [sic] muy grande, lo enterró en parte húmeda porque las letras se carcomiesen algo y para el día señalado, después de aber discurrido largíssimamente el Dr. Siruela sobre la inteligencia de las cinco letras SSSSS, le dijo el Sacristán donayrossísimamente: Mire, Sr. Dr. no se canse que no entiende de estas materias; yo no sé latín y tengo de declararle esta inscripción, sin que tenga duda lo que quieran decir las cinco $S$ es esto: Sebastián Sánchez Sacristán de San Salbador. Corrióse dicho Dr. y fué muy risible la burla, como lo será las más veces que lleguen a interpretarse algunas piedras antiguas que solo constan de notas y no de raçones continuadas ${ }^{82}$. De toda esta actividad historiográfica y anticuaria de Vázquez Siruela quedan múltiples trazas entre sus papeles. Lo que quiero señalar aquí es que él, como otros eruditos de su tiempo, creía que el árabe y el hebreo eran herramientas necesarias para esas labores, y por ello, de una u otra manera, se acercaron a la lengua y a los libros orientales, y más en concreto, árabes. Así, en una carta del 30 de junio de 1653, Nicolás Antonio presentaba a Vázquez Siruela un nuevo amigo, posible corresponsal en materias históricas, llama-

81 Woolard, K., «Bernardo de Aldrete, humanist and laminario», Al-Qantara (Madrid) 24 (2003), 449-476. Merece aún un estudio detallado otra obra de Aldrete, Varias antigüedades de Espa$\tilde{n} a$, África y otras provincias, Amberes, 1614, dentro de este ambiente intelectual, religioso e historiográfico.

82 Gallego Morell, Antonio, Francisco y Juan de Trillo y Figueroa, Granada, Universidad de Granada, 1950, 101. 
do fray Thomás de León. La comunicación con éste, decía Nicolás Antonio, «le a de ser a Vuestar Merced de mucho uso i utilidad para lo Hebreo i Árabe de los Orígines Béticos» ${ }^{83}$. Parece que Vázquez Siruela estaba trabajando en una obra sobre los orígenes de la Bética, para la cual le era necesario recurrir a lo escrito en esas dos lenguas. No es de extrañar, pues, que entre su correspondencia con los granadinos que fueron enviados a Roma junto con los libros, se halle una lista de libros en árabe que fray Bartolomé de Pectorano sugería podía encargar el racionero de Sevilla: «Evangelia Arabica toํ. 1. / Psalterio Arabico to 1. / Thesaurus Arabicus Antonij Gigeé ${ }^{\text {os }}$. 4. / Thesaurus Arabicus del Padre Novara to․ 1. / Fabrica Arabica to․ 1. / Ajurrumill $\mathrm{t}^{\circ}$. 1. / Gramatica de Marteloto $\mathrm{t}^{\circ}$. 1. / Gramatica de Guadañolo - $\mathrm{t}^{\circ}$. 1. / Apologia de Guadañolo - $\mathrm{t}^{\circ}$. 1. / Lexicum Arabicum de Rafalengio. - $\mathrm{t}^{\circ}$. 1. / Gramatica de Herpenio - $\mathrm{t}^{\circ}$. 1./ Testamentum novum Arabicum de Herpenio to ${ }^{\circ}$. $1 .{ }^{84}$. Esta lista merecería más comentarios de los que se pueden hacer aquí. Además de los nombres de arabistas y orientalistas ilustres como Erpenius o Raphelengius, la propuesta de compra incluía algunas de las publicaciones sobre la lengua árabe más importantes realizadas en Italia en las primeras décadas del s. XVII, desde los diccionarios de Antonio Giggeo (Thesaurus linguae Arabicae, Milán, 1632), Domenico Germano (Fabrica overo dittionario della lingua volgare arabica, et italiana, Roma, 1636), o Tommaso Obicini de Novara (Thesaurus Arabico-Syro-Latinus, Roma, 1636), hasta textos apologéticos y polémicos cristianos, como la Apologia christiana religione de Philippo Guadagnoli (Roma, 1631). Es significativa la inclusión en la lista de la Aŷurümiyya, gramática compuesta por el lingüista fesí Ibn al-Aŷurrūm a comienzos del s. XIV, y que tendría una enorme difusión en todo el mundo árabo-musulmán, y también en Europa, donde fue traducido diversas veces al latín ${ }^{85}$, y empleada como manual del aprendizaje del árabe, por ejemplo, por algunos maestros de Universidad de Salamanca, como Hernán Núñez, el Comendador Griego ${ }^{86}$.

No podemos saber si, finalmente, Vázquez Siruela compró todos o sólo algunos de estos libros. La noticia, en todo caso, debe ser completada con otras referencias, no poco numerosas, a los libros árabes que circulaban por España en la época, la mayoría de ellos impresos en talleres europeos. Así, por ejemplo, en el mismo epistolario citado se encuentra una carta de Juan Bautista Centurión a Vázquez Siruela, donde utiliza dos de los diccionarios árabes citados, el

${ }^{83}$ Papeles varios de Martín Vázquez Siruela, Real Biblioteca de Palacio, mss, cit., f. 52r.

${ }^{84}$ Papeles varios del Sacro Monte, BNM, mss cit., f. 111v.

85 Troupeau, G., «Trois traductions latines de la 'Muqaddima' d'Ibn Āgurrūm», Études d'orientalisme dédiées à la mémoire de Lévi-Provençal, París, 1967, I, 359-365. Posiblemente, la traducción a la que se refiere el texto que comento es la realizada por Tommaso Obicini, Grammatica Arabica Agrumia apellata, Roma, 1631, editada significativamente, como muchos de los textos citados, por la Sacra Congregazione de Propaganda Fide. Un borrador de traducción castellana de esta obra (y de la Kāfiya de Ibn al-Hâŷyib), posiblemente del s. XVII, se encuentra en la BNM, mss. 7887.

86 BATAILlON, M, «L'arabe à Salamanque», 9. La referencia está tomada de la apasionante narración que el propio Nicolás Clénard hace de su aprendizaje del árabe, y en general de todo su viaje por España y Marruecos. 
de Raphalengius y el de Giggeo, para aclarar el sentido original de varias palabras, $f \bar{a} t \bar{u} s \bar{a}$, albarrana, y sultán ${ }^{87}$. En general, el de Vázquez Siruela es sólo un ejemplo, como veremos, de un círculo de eruditos entre cuyos intereses filológicos, arqueológicos e historiográficos, ocupaba un lugar importante el árabe, al lado de otras lenguas orientales. Seguramente, Vázquez Siruela no llegó a alcanzar un gran dominio del árabe, aunque se conservan documentos de su mano con distintas pruebas de alifatos árabes ${ }^{88}$. El suyo es un caso parecido, en cierto modo, al de un contemporáneo con el que compartía, entre otras cosas, el interés profundo y comprometido por la poesía de Góngora: me refiero a José Pellicer de Ossau y Tovar. Tampoco puedo entrar con profundidad en el estudio de su figura, y sólo señalaré que, no por azar, su relación con la lengua árabe tiene unas causas similares a las que empujaban a Vázquez Siruela. Es él mismo quien cuenta el origen de ese interés: «Avisos de 30 de abril de 1641. [...] Ha habido estos días junta de cronistas sobre el modo que puede haber en ajustar lo que Su Santidad que se lleven originales los libros arábigos que se hallaron en el Monte Sacro de Granada, que están escritos en plomo, y debajo de la censura de la Inquisición, y los guardan en San Gerónimo de Madrid, al lado del Evangelio. S. M. rehúsa los lleven originales para la calificación que el Papa quiere hacer de lo escrito. Acá pretenden que venga legado con toda la plenipotencia apostólica, y para conferir los ejemplares se juntaron los cronistas Gil González Dávila, don Tomás Tamayo de Bargas y don Josef Pellicer, cronista mayor, a quien ha mandado S.M. estudie la lengua arábiga por lo que sucediere, de si junta Concilio Nacional» ${ }^{89}$. Es muy posible que Pellicer no se entregase jamás decididamente al estudio del árabe. Sus papeles, sin embargo, que acumulan materiales diversos para la realización de su trabajo cronístico, contienen múltiples referencias a la manera en que él pensaba documentar las noticias sobre el Islam, o sobre la historia de los árabes en la península Ibérica. Junto a las referencia obligadas, por ejemplo, a la Corónica de los Moros de España de Jaime Bleda, la Historia del rebelión y castigo de los moriscos de Luis del Mármol o, incluso, la apócrifa traducción de Miguel de Luna a la que ya he aludido más arriba, la Verdadera Historia del rey d. Rodrig $0^{90}$, se pueden encontrar otras referencias: así, una amplia traducción de todo lo referente a la vida del profeta Muhammad y al origen de la religión musulmana contenida en la antiguamente llamada Crónica de Isidoro Pacense ${ }^{11}$, fuente cuya importancia para la historia del s. VII es bien conocida. Más interesantes para este artículo, sin embargo,

\footnotetext{
87 Papeles varios de Martín Vázquez Siruela, Real Biblioteca de Palacio, mss. cit., f. 177.

88 Archivo de la Abadía del Sacromonte, leg. I, $1^{\text {a }}$ parte, f. 1530.

89 Pellicer de Ossau y Tovar, José, Avisos históricos, selección de Enrique Tierno Galván, Madrid, Taurus, 1965, 103-4.

90 Pellicer de Ossau y Tovar, José, Obras varias, tomo V, BNM, Mss. 2239, f. 88v y ss.

${ }_{91} I d$., f. $245 \mathrm{r}$ y ss. «Incipit Epithoma Imperatorum vel Arabum Ephemerides, atque Hispaniae Chronographia sub uno collecta ab Issidoro Paccensi Episcopo». V. SUMNER, G.V., «José Pellicer y la «Crónica mozárabe» de 754», Emerita, 49 (1981), 61-4.
} 
son otros papeles del propio Pellicer, titulados «Apuntamientos sacados de la Historia Sarracenica compuesta por Gregorio Elmacino Hijo de Abuljaser [...] Tradujo esta historia de la lengua Arábiga en la latina Tomás Erpenio, de un M.S. de la Biblioteca de Heidelberg [...]»92. Efectivamente, durante 40 folios, Pellicer toma notas extraídas de la famosa crónica de $\hat{Y}$ irŷis b. al- ${ }^{\circledR}$ Amīd, llamado al-Makīn, autor copto del s. XIII. La obra de al-Makīn, titulada alMâym $\bar{u}$ al-mubārak, o simplemente al-Ta'ríj (Historia), es una historia universal desde la creación del mundo hasta $1260^{93}$, que fue pacialmente editada y traducida al latín por el gran arabista flamenco Thomas van Erpen, o Thomas Erpenius, en $1625^{94}$. La figura de Erpenius es bien conocida ${ }^{95}$, así como la gran importancia de su labor de erudito y de editor, que realizó en la Typographia Erpeniana Linguarum Orientalium de Leiden durante el primer cuarto del s. XVII. Es también conocida la correspondencia que mantuvo con el arzobispo d. Pedro de Castro en 1623-4, cuando éste pretendió traerlo a Granada para traducir los libros Plúmbeos. En esa correspondencia, conservada en el Archivo de la Abadía del Sacromonte, se contiene, por ejemplo, la traducción latina de cinco láminas sacadas de los Plomos que Erpenius realizó como prueba ${ }^{96}$. La Historia Sarracenica de Giorgio Elmacino, impresa póstumamente en la Typographia Erpeniana, fue un libro significativo en cuanto a su importancia para el conocimiento de la historia arabo-musulmana en Europa, incluyendo España, como muestran los papeles de Pellicer. Significativamente, al final de estos Apuntamientos, Pellicer añade lo que parece ser un programa para escribir la historia de la conquista árabe de España: «Año fijo de la perdida / quien fueron los que la ganaron, i origen de Mahoma / Distincion entre los Sarracenos, Agarenos i Moros / La Mauritania entonces de España / Quienes fueron los que la perdieron / Pronosticos de la Perdicion / Descripción de lo que poseian los Godos / Batalla de la Perdida segun Servando / Como se fue perdiendo hasta apoderarse della los Moros» ${ }^{97}$. Aunque, como en el caso de Vázquez Siruela, mu-

92 BNM, Mss 11146, ff. 83 y ss.

93 Pleissner, M., «al-Makīn», Encyclopédie de l'Islam, 1a ed., Leiden, vol. III, 183b-184b; CAHEN, C. y CoQuin, R.G., «al-Makīn b. al- 'Amīd», EI², VI, 143b-144b.

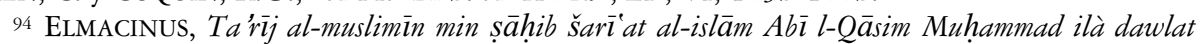

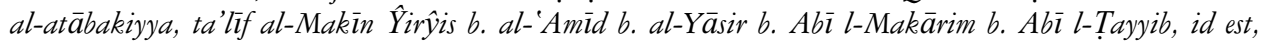
Historia Saracenica (...). Arabicè olim exarata à Georgio Elmacino fil. Abuljaseri Elamidi f. Abulmacaremif. Abultibi. Et Latine reddita operâ ac studio Thomae Erpenii. Accedit E Roderici Ximenez, Archiepiscopi Toletani, Historia Arabum, longè accuratius, quam antè, è Manuscripto codice expressa, Leiden, 1625. Como se ve, el volumen incluye una edición de la Historia Arabum de Rodrigo Ximénez de Rada.

95 Para referencias sobre su vida y obra, y sobre otras particularidades del arabismo holandes, v. Wiegers, G.A. A learned Muslim Acquaitance of Erpenius and Golius: Ahmad b. Kāsim al-Andalusī and Arabic Studies in the Netherlands, Leiden, 1988.

96 Para todo este episodio, v. Martínez Ruiz, J., "Cartas de Thomas van Erpen (Thomas Erpenius) en un Archivo de Granada (1623-24)», Boletín de la Real Academia Española, 55 (may.-ago. 1975), 267-306.

97 BNM, Mss 11146, f. 123v. 
chos de los proyectos historiográficos de Pellicer quedaron frustrados, sus esfuerzos muestran la manera en que la influencia de los libros producidos por el orientalismo europeo iba introduciéndose, en una cierta medida, en la narrativa elaborada acerca de la historia de los musulmanes en España.

Aparentemente, ni José Pellicer ni Martín Vázquez Siruela llegaron a dominar la lengua árabe, aunque quizás más éste último. Sin embargo, su preocupación por la erudición oriental y por el aprendizaje de lenguas orientales era un rasgo que compartían con otros intelectuales de su mismo círculo. Entre las abundantes cartas que este grupo de eruditos españoles de la segunda mitad del s. XVII intercambiaron entre sí se pueden encontrar varios ejemplos, algunos muy notables, de interés para diversas cuestiones árabes y orientales, desde informaciones toponímicas y etimológicas, o noticias concretas sobre el significado de algunas voces árabes, hasta cuestiones historiográficas más complejas. Sin querer multiplicar los ejemplos sobre este material, citaré solamente dos casos. El primero, en el que se adivina una carrera frustrada de arabista, es el de Juan Durán Torres, que llegó a alcanzar un cierto conocimiento del árabe. El texto de una carta que envió a su mentor Vázquez Siruela, respondiendo a una consulta de éste, es significativo: "Ya Vuestra Merced conocerá quánto lugar se avrán [?] hecho en mi estimación sus advertencias i elogios no merecidos, pues se lo hace entre la modestia a no poca costa, tal a sido la que a tenido en este estudio de mi Árabe. I por cumplir sin mas dilación con lo que Vuestra Merced me manda le [...] de él; digo, señor, que en quanto toca a lo geográfico no se detiene, ni describe [...]dan ${ }^{\text {te }}$, provincias, o ciudades, si sólo lo universal de la geografia árabe por sus climas, y la situación con generalidad, sin grados ni alturas, sino sólo con algunas señas muy generales, como son las vezindades de otras regiones, v.g. de los francos شمالي اندلس, ad septentriones Hispaniae, de la Hindia غربي الهند, ad Occidedentis [sic] Indis, i de este modo en otras. De la Isla Verde i Almería no haçe mencion en parte alguna, i de los lugares de la Bética de قرطبه Córdoba, de que hace especial mención en una donación de Abderramán de el lugar para Iglesia el año de ciento y setenta de la Hégira, de Granada غرناطه, de Sevilla اشبله [sic]. Ai otro lugar mui insigne de un Rei de Sevilla, poeta y desastrado en su fin, que fue depuesto i preso, i un epigramma suio [...] $»^{98}$. Durán Torres, según la noticia que de él da Nicolás Antonio, era sevillano, había estudiado derecho civil y canónico en Salamanca, y había acompañado a Roma al Cardenal Pimentel, como jurisconsulto en cuestiones

98 Carta de Juan Durán de Torres a Martín Vázquez Siruela, Madrid, 22 de marzo de 1661, Papeles varios de Martín Vázquez Siruela, Real Biblioteca de Palacio, mss. cit., f. 164. 
canónicas. Murió joven ${ }^{99}$, dejando inacabada una traducción árabe a la que me referiré más abajo ${ }^{100}$.

El segundo caso que quiero tratar me parece más interesante, y se refiere a un personaje que ya he citado más arriba, el jesuita Thomás de León que, como se recordará, era presentado por Nicolás Antonio a Vázquez Siruela como el hombre idóneo con quien consultar «lo hebreo i árabe de los orígines Béticos». En efecto, Thomás de León parece haber llegado a un alto grado de conocimiento de lenguas y asuntos orientales, como queda reflejado en su correspondencia con Vázquez Siruela, Antonio de Araoz, Cristóbal de Mendoza o el Marqués de Mondéjar. El retrato que hasta ahora ha dado la historiografía de Thomás de León tiene, hasta donde yo conozco, un carácter bastante fragmentario. Por un lado, se ha subrayado el interés de parte de las cartas que intercambió con Mondéjar, importantes para comprender el esfuerzo intelectual e historiográfico en que estaba implicado ese grupo de eruditos «preiluministas» españoles de la segunda mitad del XVII, cuya figura central fue, quizás, el propio Mondéjar ${ }^{101}$. Por otro lado, Darío Cabanelas dio cuenta de la existencia de un diccionario arábigo-latino y arábigo-castellano, que se conserva manuscrito en la Escuela de Estudios Árabes de Granada, y con él, de una brevísima reseña de su vida y de parte de sus obras ${ }^{102}$. El padre Thomás de León nació en Irlanda en 1613, aunque fue traído a España siendo aún un niño. Afincado en Granada, acabó siendo profesor en el Colegio de S. Pablo de esa ciudad, y murió el 7 de febrero de 1690. Parte de su producción escrita nos lo muestra como experto en derecho, respondiendo a cuestiones como «Si quedan irregulares unos clérigos que forman compañía para armar un bajel», o «Si puede el Obispo conmutar las últimas voluntades después del decreto tridentino», entre

99 V. Carta de Nicolás Antonio a Juan Lucas Cortés, Roma, 1 de septiembre de 1663. «Faltò en nuestro Don Juan Duràn un sugeto de grandes esperanzas, i que nos pudieran honrar la Nacion. Yo oì su muerte con gran sentimiento por lo que le amava, i estimava. Terrible carestìa de salud pasa por los Literatos de nuestra Patria, halladose mi buen Dotor Siruela en el estado que U.M. me dice, i el Señor Don Iuan Suarez en el de no poder atender ni aun a la obligación del oficio [....]», en Antonio, Nicolás, Censura de historias fabulosas. Antecedida de su biografía por d. Gregorio Mayàns y Siscàr. Se añaden cartas de Nicolás Antonio y otros eruditos, Madrid, 1742, reimp. facsímil Madrid, ed. Visor, 1999, 646.

100 AnTONio, Nicolás, Biblioteca Hispana Nueva, I, 728.

101 V., por ejemplo, ARIZPE, Víctor, «Don Gaspar Ibáñez de Segovia, marqués de Mondéjar, 'Rey y Príncipe de la Erudición de España': un novator de la segunda mitad del siglo XVII», en E. Artaza, J. Durán, C. Isasi, J. Lawand, V. Pineda y F. Plata (coords.), Estudios de Filología y Retórica en Homenaje a Luisa López Grigera, Bilbao,Universidad de Deusto, 2000, 31-43, especialmente 39-41.

102 Cabanelas, Darío, «Vocabulario arábigo-castellano y arábigo-latino inédito», Miscelánea de Estudios Árabes y Hebraicos (Granada) 28 (1979), 209-214. El vocabulario en cuestión se encuentra hoy en día en la Escuela de Estudios Árabes de Granada, mss. XVII. Agradezco a Miriam Font las facilidades que me ha dado para acceder a este texto. 
otras $^{103}$. Pero la parte central y más interesante de su producción intelectual estuvo dedicada a cuestiones de erudición oriental, ciertamente apartadas de su dedicación profesional, y del interés de la mayoría. Como él mismo expresaba en una carta dirigida posiblemente al Marqués de Mondéjar, «si Vuestra Señoría conociera la cantidad numeral de mis occupaciones, confessaría con satisfación lo que me arrastra una inclinación apassionada a estos estudios. Y aviendo conocido a Vuestra Señoría puedo vivir gustoso, pues e desecho el baldón con que me motejaron mis amigos por el estudio de las lenguas orientales. Letras que sólo las aprecia Rachman y D. Lu. [?] (es el primero un moro Altaleb o Estudiante de aquí y un Judío de Orán con quienes me veen comunicar)»104. Esta ocupación, sin embargo, constituía, en palabras de Mondéjar, «la llave del verdadero saber»: «[...] pero con toda ingenuidad confiesso que para mí es de mayor estimaçión el sentir de V.P. que el de quantos conozco y comunico en [Espa]ña; venero a todos por doctos en su profeçión pero raríssimos que en todas tengan con extenssión la profundidad y la conprehensión de las lenguas orientales, llave $\mathrm{d}[\mathrm{el}]$ verdadero saver $\left[\ldots . . .{ }^{105}\right.$. En efecto, las palabras de Mondéjar no parecen una alabanza exagerada, pues el padre Thomás de León fue sin duda uno de los españoles más expertos en lenguas orientales de su generación. Así lo demuestran la amplitud de sus intereses y de su erudición, nutrida por la frecuentación de las novedades bibliográficas europeas. Es imposible agotar aquí la lista de los temas tratados y de los libros citados en la apasionante correspondencia entre Thomás de León y el Marqués de Mondéjar, que incluye también a otros eruditos como Vázquez Siruela: desde un amplio ensayo sobre la antigüedad de los caracteres salomónicos (en que, como se recordará, estaban escritas las falsificaciones del Sacromonte) ${ }^{106}$, hasta discusiones sobre el origen de las arras españolas (una costumbre, según el padre León, de origen hebreo y oriental) ${ }^{107}$, o sobre si Moisés fue el primer hombre que utilizó la es-

${ }^{103}$ Biblioteca de la Universidad de Granada, Mss. BHR/Caja A-042, passim. Dos manuscritos de la Universidad de Sevilla contienen otras obras teológicas de Thomás de León (De incarnatione, mss. 332-38, y Explicatio distinctionis virtualis in divinis per sua principia exposita, mss. 333-18-IV) que no he tenido oportunidad de consultar.

104 Papeles varios de erudición, BNM, mss. 9881, f. 3r. En otro lugar, Thomás de León confesaba «que es desconsuelo no aver por acá con quien comunicar estos estudios; y aunque yo e procurado quanto e podido pegar la afición a discípulos y amigos; pero puede más la dulzura del no trabajar que la suavidad que ay en bever de las fuentes; entender las almas mayores del mundo como ellas se declararon y no como otros las explicaron", id. $23 \mathrm{r}$.

${ }_{105}$ Carta de 18 de junio de 1659, probablemente de Mondéjar a Thomás de León, id., f. 225.

${ }^{106} I d$., f. 110r y ss. Esta disertación, crítica con el argumento que afirmaba que estos caracteres eran antiquísmos, y que habían sido ofrecidos por el rey Salomón a la reina de Saba, o bien que habían sido tomados por los árabes de los sirios o los fenicios, es obra probablemente del Marqués de Mondéjar.

107 Quizás se trate del mss. de la Biblioteca de la Universidad de Granada, «Arras españolas: qué sean y su origen», BHR/Caja A-042 (8), que no he podido, aún, consultar. 
critura $^{108}$. Son interesantísimas las páginas dedicadas a las antigüedades egipcias, y al origen e historia del copto. En este sentido, los intereses intelectuales de fray Thomás de León coincidían, en parte, con los de Athanasius Kircher, cuya bibliografía es ampliamente utilizada y citada en esta correspondencia, y con quien el jesuita granadino mantenía contacto epistolar ${ }^{109}$. El de Kircher es sólo un ejemplo que demuestra una sigular apertura a la historiografía europea, y la manera en que ésta circulaba entre estos eruditos españoles. Así, por ejemplo, de su correspondencia se deduce que el Marqués de Mondéjar dio a conocer a fray Thomás de León las obras de Hottinger ${ }^{110}$, y también las primeras noticias de las de Wilhem Schickard, que juntos comenzaron a discutir y a leer ${ }^{111}$. En otro momento, y a propósito de la historia antigua de Egipto, Mondéjar habla a Thomás de León de un manuscrito árabe que posee: «El libro árabe que ofreçí a V.P. está escrito en Otavo en Vitelas y raçonable carácter con aquella variedad de colores frequente en los libros escritos con cultura, y por de fuera tiene por título sobre las mismas hojas esta inscriptión [blanco] la qual se repite en la segunda hoxa [blanco] nominatio de que mi sentir es lo mismo es que Campi disputationem in doctrina seu sapientia prinçipiorum et finium. Empieça poniendo relaçiones de la Creaçión del mundo, señalando los autores de quien toma, repitiendo varias veçes la palabra, conque divide el sentir de cada uno. No he podido reconoçer lo demás, porque como tengo escrito a V.P. no tengo muy suelto el uso desta lengua $\left[\ldots . .{ }^{112}{ }^{112}\right.$ Los blancos que aparecen en este texto deberían incluir, sin duda, el texto árabe del título de ese libro, que conocemos por la respuesta de fray Thomás de León: se trata de la Raw dat al-manāzir fì 'ilm al-awā'il wa-l-awājir del juez egipcio Abū l-Walīd Muḥammad Ibn al-Šịnna, una especie de resumen del ya citado Mujtaṣar ta'rīj al-bašar de Abū l-Fidā. A este manuscrito se refiere varias veces fray Thomás de León en sus escritos. En uno de ellos, coincidiendo con la muerte de Juan Durán Torres, dice: «Muchísimo sentí el malogro de D. Juan Durán de Torres:

${ }_{108}$ Carta de Thomás de León al Marqués de Mondéjar, Granada, 10 de junio de 1659, Papeles varios de erudición, $\mathrm{BNM}$, mss. cit., f. $52 \mathrm{r}$ y ss.

109 De hecho, al comienzo de su correspondencia con Mondéjar, el padre León confiesa haber buscado primero, para saciar su curiosidad intelectual, corresponsales extranjeros, cuando lo más valioso (es decir, el propio Mondéjar) se encontraba en España: «Lo segundo de que pido perdón es de aver escrito a Vuestra Señoría como cavallero erudito de nuestro Paýs: n[?] de noticias tan selectas como arcanas; y aora beso a Vuestra Señoría los pies como Rey i Príncipe de la erudición de España. Esto, señor, es saver como ninguno save de quantos yo conosco! E mostrado la carta con admiración mía y de quantos saven de [la] materia y la an visto. Asseguro a Vuestra Señoría que no e visto papel en muchos años que más me aya humillado ni obligado más a estudiar y viendo quán lexos andava buscando yo en correspondenc[ias] estrañas, en África con Samuel Zaporta; en Holanda con Will. Vorstio», carta Thomás de León al Marqués de Mondéjar, de 25 de marzo de 1658, $i d$., f. 36r. El propio Marqués de Mondéjar se escribía con Kircher (id., f. 221 y ss.).

$110 \mathrm{~V}$., por ejemplo, id., 33r.

${ }_{111} I d .$, ff. $241 \mathrm{v}-242 \mathrm{r}$.

112 Id., 229 r. 
yo vi hasta unos doze quadernos de la traductión que tenía hecha y muy de veras le dije mi sentimiento de lo bien que me parecía la obra; palabra por palabra bolvía revisto y annotado el pliego que me embiava hasta la última semana de su muerte. El original nunca le vi; antes ofreciendo a su hermano el reveer lo que restava, no he tenido más noticia; y assí Vuestra Señoría no pierda el original, sino mande poner diligencia en cobrarle, porque quedando, en manos de gente ignorante, queda arriesgado. D. Juan se consoló muchísimo quando vio que las generaciones que pone antiquíssimas de los Árabes y Príncipes de varias generaciones del Iaman están sin descrepar en mi Giauhari, que tiene 400 años de Escritura (quando florecían los Reyes moros de Granada.). El Author del Chrónico es estimado y le está de ordinario. Abrahamo Ecchelense, De origine nominis Papa et de originibus Ecclesia Alexandrinae contra Seldeno y Hottingero, y folio 319 dél, muestra, entre otros vulgaríssimos yerros deste último, muestra quiénes eran y son los Sabaítas, su nación y religión, y en el Índice de los Árabes MS. en la M. pone محمد بن الشحنه Mahamed ben Alsachena chronico»113. Aunque los términos de la redacción no están claros, se entiende que la traducción en la que Juan Durán Torres estaba trabajando cuando murió era precisamente la de esta obra de Ibn al-Šịnna ${ }^{114}$, que de manera tan favorable comentaban Mondéjar y Fray Thomás de León.

No puedo comentar aquí con excesivo detalle los libros citados y manejados por fray Thomás de León ${ }^{115}$ y sus corresponsales, y que constituyen repaso notable de la bibliografía sobre temas orientales, árabes, hebreos, sirios, etc., que circulaba por Europa en aquellos momentos. En una de las cartas, en la que fray Thomás de León trata el tema de si los libros que se imprimían en árabe tenían o no vocales, le escribe a Antonio de Araoz: «yo no puedo discurrir ni responder a obiectiones quando tengo evidencia de lo que digo. Téngola con toda evidencia de lo que digo de los libros Árabes impressos sin mociones y e visto quantos se an impresso hasta el año de 1640 en Europa ni Erpenio puede decir contra esto pues los libros que él imprimió los tengo y ninguno tiene mociones como es palmario» ${ }^{116}$. Como pequeña muestra de lo que decía, en una

113 Carta de Thomás de León al Marqués de Mondéjar, 3 de junio de 1664, id., f. 25v.

${ }_{114}$ Unos papeles dentro del mismo manuscrito, sin encabezamiento, y por lo tanto de dudosa atribución de momento, parecen referirse precisamente a esta traducción: «La curiosidad y la persuaçión de algunos acuyo respecto no pudo faltar mi obediençia me hiço emprender la traduçión desta historia de Egipto, y aunque reconoçí desde los umbrales de su fábrica la ynçertidumbre de los materiales de que se formaba, me pareçió sin embargo se mezclavan entre ellos notiçias no vulgares, espeçialmente al estilo español, tan remoto de las costumbres, ritos y govierno de los Orientales, y que no desagradaría su leç̧ión, si la preçediesen aquellos advertimientos de que neçessitan por la mayor parte las obras todas que compuestas de ymfieles se haçen públicas al teatro Cathólico [....]», id., f. 255r. Nicolás Antonio (Biblioteca Hispana Nueva, I, 728), se refiere a esta traducción inédita como Abwalid Ben Schacenas Chronico Generale.

115 En la actualidad, estoy preparando un estudio monográfico sobre Fray Thomás de León, donde espero tratar este y otros asuntos.

116 Carta de Thomás de León a Antonio de Araoz, Granada, 22 de julio de 1659, Papeles varios de erudición, BNM, mss. cit., f. 13 r. 
carta anterior ya había hecho un mínimo repaso a los libros a su alcance: «En quanto a los libros Árabes que se imprimen que son sin puntos los más y raríssimo el que los tiene: es tan evidente que nada más cierto. Yo tengo los evangelios estampados en Roma: el Geógrapho Árabe, La Historia de Elmacino, la Ley de Moysés o Pentateucho, el nuevo testamento impresso por Erpenio. En el Sacro Monte está Euclides Árabe, Politor speculi, Legationes Cairi, Giarrumía, Caphia, Tasrif y otros muchos sin mociones. Impresso con mociones no e visto sino el Salterio de Savario, la Doctrina christiana de Richelio; ambos tengo yo. En la librería de S. Hermenegildo vi dos Centurias de Proverbios de Abi Beud impressos en Holanda, con mociones y escritura perfecta como la del Alcorán [.... $\gg^{117}$. Los comentarios hechos en el discurso de los distintos temas tratados demuestra que fray Thomás de León manejaba con soltura estos y otros libros, y que estaba al tanto de todo lo que, sobre estudios orientales, se estaba produciendo en Europa.

Como queda dicho, el padre Thomás de León fue corresponsal de Athanasius Kircher ${ }^{118}$, quien reprodujo alguna de las cartas del jesuita granadino en su Oedipus Aegyptiacus ${ }^{119}$. En este lugar, y en un capítulo dedicado la la «magia jeroglífica», se encuentran las noticias que Tomás de León envió a Kircher a propósito de un sello mágico que él había visto en España. Hay, también, una información sobre unas inscripciones antiguas que se encontraban en el Santuario de la Cruz de Caravaca y que, según decía Thomás de León, el peritísimo arabista Miguel de Luna había interpretado como textos árabes, y traducido en consecuencia. Ambas, inscripción y traducción, se encuentran reproducidas en el texto de Kircher. Según Luna, la primera de esas extrañas y antiguas inscripciones decía: "Anno 594, Arabum Mahomat Abuzeit Rez potentissimus, \& triginta homines in hoc habitaculo conuersi fuerunt ad veram legem Saluatoris, $\&$ hoc Dei gratia, Cruce duplicata fauente, quam Angeli Dei attulerunt, \& alij multi cos iuuantes ad celebrationem, ad quorum memoriam hae litterae fuerunt celatae» ${ }^{120}$. El padre Tomás de León, y con él Athanasius Kircher, sospechaba con razón de la impostura de Miguel de Luna, que quería convertir en árabes lo que eran «characteres Punici antiqui à Gothis corrupti». Sabemos, en efecto, que Luna había realizado esta traducción fantástica que pretendía, aparentemente, apoyar la famosa historia de la conversión del rey musulmán Abuzeyt, y de la milagrosa aparición de la Cruz de Caravaca; historia que conoció una gran pujanza en esta época y con la que, según parece, Miguel de Luna intentaba demostrar la conversión de musulmanes al cristianismo antes del s.

117 Carta de Thomás de León a Antonio de Araoz, Granada, 10 de junio de 1659, id., f. 12r.

118 Aunque no es citado entre los corresponsales españoles de Kircher en GLICK, Thomas, «On the influence of Kircher in Spain», Isis, 62 (1971), 379-381.

119 Kircher, A., Oedipus Aegyptiacus ad Ferdinandum III Caesarem semper augustum, 4 vols., Roma, Vital Mascardus, 1653, IV, 481 y ss.

$120 I d ., 487$. 
$\mathrm{XVI}^{121}$; nada de extraño en un personaje que fue, como se ha visto, uno de los posibles autores de las falsificaciones del Sacromonte, y que añadía así una prueba autorizada más en su estrategia de legitimar la cultura árabe por vía de la desislamización. Curiosamente, el propio Athanasius Kircher fue uno de los responsables de que la Iglesia de Roma determinase, finalmente, la falsedad de los libros de Plomo de Granada.

Quizás el asunto de los Plomos del Sacromonte no fue, como quería el arzobispo d. Pedro de Castro, la ocasión más grave que había vivido la humanidad desde tiempos de Adán. Aquellas extrañas láminas de plomo, escritas en caracteres difícilmente legibles, repletas de signos mágicos, en una lengua directamente relacionada con un secular enemigo militar y religioso, suscitaron sin embargo cuestiones sumamente importantes para la España de su tiempo, relativas a la lengua, al origen de España, a la vinculación de la iglesia española con la historia sagrada, a la integración del pasado árabo-musulmán de la Península en la construcción de una historia y de una identidad hispánicas. Todas estas cuestiones sobrepasaban, desde luego, el ámbito erudito, y conectaban con asuntos importancia acuciante: la cuestión de los moriscos, las relaciones con Marruecos o el enfrentamiento con los Otomanos. Todos estos asuntos están mezclados de forma inextricable, y explican en buena medida la singularidad del orientalismo español en relación al europeo. Explican también por qué un fraude como el de los Plomos del Sacromonte movilizó tal cantidad de esfuerzos intelectuales, religiosos y políticos, y por qué sus derivaciones atraviesan tantos problemas diferentes. El ambiente intelectual suscitado en torno a los libros plúmbeos se prolonga, creo, durante todo el s. XVII, y cristaliza en una serie de esfuerzos que me parecen relevantes. El hecho de que en ese momento se acometieran en España traducciones de obras árabes, como la de Ibn al-Šihna o Abū l-Fidā (que tan importante habría de ser después para todo el orientalismo europeo) muestra que las preocupaciones intelectuales que existían en España no diferían mucho de las del resto de Europa, donde se produjeron obras tan importantes como la edición y traducción de la Crónica de Elmacino por Erpenius. Parte de la singularidad del caso español con respecto al europeo se encuentra en el terreno de la imprenta: en efecto, lo mejor de la producción arabista española de ese periodo quedó manuscrito, atascado en el desarrollo de proyectos nunca terminados, o simplemente reflejado en la comunicación epistolar entre eruditos. Creo que este hecho es consecuencia del

${ }^{121}$ V., por ejemplo, otra versión de esta traducción de Miguel de Luna en LóPEZ YLLÁN, José, Disertacion sobre el origen è Historia de la Sta. Cruz de Caravaca, Leida en la Academia de Letras Humanas de Sevilla por..., texto de 1793 que editan Fernández García, Francisco, Pozo MarTínez, Indalecio, SÁnchez Romero, Gregorio y Marín Ruiz de Assín, Diego, La Santa Vera Cruz de Caravaca. Textos y documentos para su historia (1517-2001), Caravaca, 2003, 140-145. Hemos hecho un estudio más detallado de este asunto, comenzando por la obra de Juan de Robles Corbalán, y su relación con Miguel de Luna, en García-Arenal, M. y Rodríguez Mediano, F., «Médico, traductor, intérprete: Miguel de Luna, cristiano arábigo de Granada», Chronica Nova (Granada) (en prensa). 
particular estatuto que la lengua árabe tenía en España, y también de una cierta precariedad general en la actividad impresora en la España del XVII. A pesar de estos problemas, me parece que puede trazarse una línea de continuidad entre el s. XVII y el s. XVIII, cuando la actividad de Casiri y de otros personajes tan importantes como Campomanes vuelven a hacer presente el interés por la lengua y los libros árabes, esta vez en el marco de un proyecto ilustrado ${ }^{122}$. Si en general, dentro de la historia de la génesis de la Ilustración española, el grupo formado en torno a Nicolás Antonio o el Marqués de Mondéjar, y los asuntos historiográficos que les interesaban ${ }^{123}$, desempeñan un papel muy importante, espero haber mostrado que la erudición oriental era fundamental dentro de su propio su proyecto intelectual. Nada extraño, pues el Islam, la historia de al-Andalus o las relaciones con Marruecos conforman un grupo de cuestiones sin las que es imposible entender la historia de España desde época medieval.

122 Además de otras obras ya citadas, el arabismo español del s. XVIII ha sido objeto de algunos trabajos importantes. V., por ejemplo, CARRILlO, Juan L. y TORRES, $\mathrm{M}^{\mathrm{a}} \mathrm{Paz}$, Ibn al-Baytar y el arabismo español del XVIII. Edición Trilingüe del prólogo de su "Kitab al-chami», Benalmádena, 1982; FERnÁndeZ, Paz, Arabismo español del s. XVIII: origen de una quimera, Madrid, 1991. Ignacio Márquez Rowe me señala otro título pertinente: DEL Olmo LETE, Gregorio, Semitistas catalanes del siglo XVIII, Sabadell, 1988.

123 V., por ejemplo, PÉrez MAGAllón, Jesús, Construyendo la modernidad: la cultura española en el tiempo de los novatores (1675-1725), Madrid, 2002, y en especial 163 y ss., con su alusión al asunto de los Plomos. 